Article

\title{
Investigation of the Efficacy of a Postbiotic Yeast Cell Wall-Based Blend on Newly-Weaned Pigs under a Dietary Challenge of Multiple Mycotoxins with Emphasis on Deoxynivalenol
}

\author{
Debora Muratori Holanda ${ }^{1}$ (D), Alexandros Yiannikouris ${ }^{2}$ and Sung Woo Kim ${ }^{1, *(D)}$ \\ 1 Department of Animal Science, North Carolina State University, Raleigh, NC 27695, USA; \\ dmurato@ncsu.edu \\ 2 Alltech Inc., Center for Animal Nutrigenomics and Applied Animal Nutrition, 3031 Catnip Hill Road, \\ Nicholasville, KY 40356, USA; ayiannikouris@alltech.com \\ * Correspondence: sungwoo_kim@ncsu.edu
}

Received: 7 June 2020; Accepted: 3 August 2020; Published: 6 August 2020

\begin{abstract}
Pigs are highly susceptible to mycotoxins. This study investigated the effects of a postbiotic yeast cell wall-based blend (PYCW; Nicholasville, KY, USA) on growth and health of newly-weaned pigs under dietary challenge of multiple mycotoxins. Forty-eight newly-weaned pigs $(21 \mathrm{~d}$ old $)$ were individually allotted to four dietary treatments, based on a three phase-feeding, in a randomized complete block design (sex; initial BW) with two factors for $36 \mathrm{~d}$. Two factors were dietary mycotoxins (deoxynivalenol: $2000 \mu \mathrm{g} / \mathrm{kg}$ supplemented in three phases; and aflatoxin: $200 \mu \mathrm{g} / \mathrm{kg}$ supplemented only in phase 3 ) and PYCW (0.2\%). Growth performance (weekly), blood serum (d 34), and jejunal mucosa immune and oxidative stress markers ( $\mathrm{d} 36$ ) data were analyzed using MIXED procedure of SAS. Mycotoxins reduced $(p<0.05)$ average daily feed intake (ADFI) and average daily gain (ADG) during the entire period whereas PYCW did not affect growth performance. Mycotoxins reduced $(p<0.05)$ serum protein, albumin, creatinine, and alanine aminotransferase whereas PYCW decreased $(p<0.05)$ serum creatine phosphokinase. Neither mycotoxins nor PYCW affected pro-inflammatory cytokines and oxidative damage markers in the jejunal mucosa. No interaction was observed indicating that PYCW improved hepatic enzymes regardless of mycotoxin challenge. In conclusion, deoxynivalenol (2000 $\mu \mathrm{g} / \mathrm{kg}$, for 7 to $25 \mathrm{~kg}$ body weight) and aflatoxin B1 (200 $\mu \mathrm{g} / \mathrm{kg}$, for 16 to $25 \mathrm{~kg}$ body weight) impaired growth performance and nutrient digestibility of newly-weaned pigs, whereas PYCW could partially improve health of pigs regardless of mycotoxin challenge.
\end{abstract}

Keywords: aflatoxin; deoxynivalenol; pig; yeast

Key Contribution: Dietary challenge of multiple mycotoxins impairs newly-weaned pig growth by decreasing apparent ileal digestibility of nutrients. The postbiotic yeast cell wall-based blend provided similar growth; but could not overcome detrimental effects of multiple mycotoxins.

\section{Introduction}

Mycotoxins are fungal secondary metabolites, which may have deleterious effects when consumed. Mycotoxins are naturally present in several plants and products that are used as feedstuffs worldwide, where aflatoxin B1 (AFB1) and deoxynivalenol (DON) are considered major contaminants [1,2]. In the past decade, Fusarium toxins were the most prevalent mycotoxins worldwide, where DON ranked first position with $64 \%$ of feedstuff samples testing positive, whereas AFB1 was the most frequent among non-Fusarium toxins with $23 \%$ of samples testing positive [3]. 
As extensively reviewed [4-6], the pig is the most sensitive species to multiple mycotoxins, more specifically, aflatoxins, deoxynivalenol, zearalenone, and fumonisins especially in the early stages of production. Among these, aflatoxins and DON combined decrease pig growth, lead to liver damage, reduce enterocyte viability, and compromise immune function [7-9]. Aflatoxin B1 and DON present greater cytotoxicity and have caused synergistic damaging effects in porcine kidney cells [10]. Due to the high prevalence and detrimental effects of AFB1 and DON, regulatory limit levels have been established worldwide. For instance, aflatoxin is limited at 20 [11] or $10 \mu \mathrm{g} / \mathrm{kg}$ of feed [12] for growing pigs, whereas DON has advisory levels of 1000 [13] or $900 \mu \mathrm{g} / \mathrm{kg}$ of feed [14] established by the Food and Drug Administration or European Commission, respectively. Thus, there are several strategies attempting to mitigate negative effects of mycotoxins in animals, such as the implementation of prebiotics, probiotics, and adsorbents [15,16].

Components from yeast organisms, subdivided into parietal (cell wall) and intracellular content, can be used as feed additives. The cell wall consists of a carbohydrate network made of glucans, mannans and chitin $[17,18]$, the former having been identified as key components in mycotoxin deactivation [19-21] and prebiotic properties [22,23]. The postbiotic yeast cell wall, and more specifically $\beta$-D-glucans composing the inner layer portion of this network, have strong adsorbing affinity against AFB1 or zearalenone, but have limited effectiveness toward deoxynivalenol [21,24]. In addition, certain yeast cell wall components, when specifically isolated and purified, can be advantageous as a prebiotic by favoring proliferation of beneficial microorganisms, enhancing gut barrier function, and supporting intestinal health and immune function $[25,26]$.

Therefore, it was hypothesized that use of a postbiotic yeast cell wall-based blend in diets with AFB1 and DON would enhance growth, reduce liver damage, and improve immune function of newly-weaned pigs.

This study aimed at investigating the effects of a postbiotic yeast cell wall-based blend (PYCW; Alltech Inc., Nicholasville, KY, USA) on growth and health of newly-weaned pigs under chronic dietary challenges of AFB1 $(43.6 \mu \mathrm{g} / \mathrm{kg})$ and DON $(2163 \mu \mathrm{g} / \mathrm{kg})$.

\section{Results}

In the results, diets low in mycotoxins (LM) represent those formulated only with conventional feedstuffs whereas diets high in mycotoxins (HM) represent those formulated with feedstuffs including corn dried distillers grains with solubles (DDGS) high in DON and corn high in AFB1. Experimental diets were fed to newly-weaned pigs moved to the research farm in order to start the current study right after weaning.

The mycotoxin analysis performed comparing LM vs. HM diets fed to pigs show that for phases 1 and 2 the average level of AFB1 was $1.0 \mu \mathrm{g} / \mathrm{kg}$ and DON (including acetylated and glycosylated forms) was 676 vs. $2258 \mu \mathrm{g} / \mathrm{kg}$, respectively. Mycotoxin analyses performed comparing LM vs. HM diets fed to pigs for phase 3 found the level of AFB1 was $1.0 \mathrm{vs.} 44.6 \mu \mathrm{g} / \mathrm{kg}$ and DON (including acetylated and glycosylated forms) was $1311 \mathrm{vs} .4635 \mu \mathrm{g} / \mathrm{kg}$, respectively. The average mycotoxin concentration in the whole experimental period for LM vs. HM was $887 \mathrm{vs.} 3050 \mu \mathrm{g} / \mathrm{kg}$ of DON.

There were no differences in initial body weight of pigs among experimental groups. Feeding HM reduced $(p<0.05)$ average daily feed intake (ADFI) for every week and for the overall period, which resulted in reduced $(p<0.05)$ average daily gain (ADG) and body weight for all periods (Table 1$)$. The HM reduced $(p<0.05)$ ADG of pigs during the first week. There was an interaction $(p<0.05)$ for gain to feed $(\mathrm{G} / \mathrm{F})$ ratio during the first week of the study, indicating that when PYCW is added to diets, feeding HM increased $(p<0.05) \mathrm{G} / \mathrm{F}$. The interaction also indicates that in pigs fed MT, the addition of PYCW tended to increase $(p=0.062) \mathrm{G} / \mathrm{F}$ during the first week. Feeding HM also tended to increase $(p=0.057) \mathrm{G} / \mathrm{F}$ during the second week. Feeding diets with PYCW tended to reduce $(p=0.056) \mathrm{G} / \mathrm{F}$ during the overall experimental period. 
Table 1. Growth performance of newly-weaned pigs fed diets high (HM) or low (LM) in mycotoxins ${ }^{1}$ or postbiotic yeast cell wall-based blend (PYCW) for 36 days.

\begin{tabular}{|c|c|c|c|c|c|c|c|c|}
\hline \multirow{2}{*}{$\begin{array}{c}\text { Diet } \\
\text { PYCW }\end{array}$} & \multicolumn{2}{|c|}{$\mathbf{L M}$} & \multicolumn{2}{|c|}{ HM } & \multirow{2}{*}{ SEM } & \multicolumn{3}{|c|}{$p$ Value } \\
\hline & $0 \%$ & $0.2 \%$ & $0 \%$ & $0.2 \%$ & & Diet & PYCW & Diet vs. PYCW \\
\hline \multicolumn{9}{|l|}{ Body weight, kg } \\
\hline d 0 & 7.45 & 7.49 & 7.51 & 7.53 & 0.48 & 0.659 & 0.784 & 0.939 \\
\hline $\mathrm{d} 7$ & 10.11 & 9.82 & 9.33 & 9.60 & 0.69 & 0.016 & 0.970 & 0.168 \\
\hline $\mathrm{d} 14$ & 13.73 & 13.65 & 12.47 & 12.94 & 0.85 & 0.005 & 0.567 & 0.418 \\
\hline $\mathrm{d} 21$ & 17.57 & 17.71 & 15.76 & 16.24 & 0.93 & $<0.001$ & 0.475 & 0.692 \\
\hline $\mathrm{d} 28$ & 22.39 & 22.31 & 19.79 & 20.32 & 1.29 & $<0.001$ & 0.697 & 0.598 \\
\hline d 36 & 29.49 & 29.43 & 25.74 & 26.47 & 1.47 & $<0.001$ & 0.632 & 0.574 \\
\hline \multicolumn{9}{|l|}{$\mathrm{ADG}, \mathrm{kg}$} \\
\hline Phase 1 (d 0 to 7$)$ & $0.379^{a}$ & 0.333 & $0.261^{b}$ & 0.296 & 0.039 & 0.001 & 0.815 & 0.081 \\
\hline Phase 2 (d 7 to 21$)$ & 0.533 & 0.563 & 0.459 & 0.474 & 0.024 & 0.001 & 0.346 & 0.750 \\
\hline $\mathrm{d} 7$ to 14 & 0.518 & 0.547 & 0.449 & 0.476 & 0.031 & 0.017 & 0.320 & 0.980 \\
\hline d 14 to 21 & 0.549 & 0.580 & 0.470 & 0.472 & 0.038 & 0.018 & 0.667 & 0.708 \\
\hline Phase 3 (d 21 to 36$)$ & 0.794 & 0.781 & 0.665 & 0.682 & 0.039 & $<0.001$ & 0.938 & 0.553 \\
\hline d 21 to 28 & 0.688 & 0.657 & 0.576 & 0.584 & 0.055 & 0.005 & 0.714 & 0.545 \\
\hline d 28 to 36 & 0.887 & 0.890 & 0.743 & 0.768 & 0.031 & $<0.001$ & 0.624 & 0.693 \\
\hline Overall (d 0 to 36$)$ & 0.612 & 0.609 & 0.506 & 0.526 & 0.029 & $<0.001$ & 0.647 & 0.547 \\
\hline \multicolumn{9}{|l|}{$\mathrm{ADFI}, \mathrm{kg}$} \\
\hline Phase 1 (d 0 to 7$)$ & 0.310 & 0.315 & 0.239 & 0.246 & 0.040 & 0.002 & 0.765 & 0.972 \\
\hline Phase 2 (d 7 to 21$)$ & 0.651 & 0.700 & 0.559 & 0.594 & 0.039 & 0.002 & 0.170 & 0.817 \\
\hline $\mathrm{d} 7$ to 14 & 0.622 & 0.679 & 0.519 & 0.551 & 0.047 & $<0.001$ & 0.156 & 0.689 \\
\hline d 14 to 21 & 0.681 & 0.721 & 0.599 & 0.636 & 0.040 & 0.040 & 0.334 & 0.972 \\
\hline Phase 3 (d 21 to 36$)$ & 1.112 & 1.129 & 0.947 & 1.014 & 0.067 & $<0.001$ & 0.253 & 0.491 \\
\hline d 21 to 28 & 0.922 & 0.930 & 0.790 & 0.805 & 0.071 & 0.003 & 0.768 & 0.941 \\
\hline d 28 to 36 & 1.279 & 1.302 & 1.084 & 1.196 & 0.069 & 0.002 & 0.130 & 0.319 \\
\hline Overall (d 0 to 36$)$ & 0.777 & 0.804 & 0.658 & 0.701 & 0.048 & $<0.001$ & 0.191 & 0.764 \\
\hline \multicolumn{9}{|l|}{$\mathrm{G} / \mathrm{F}$} \\
\hline Phase 1 (d 0 to 7$)$ & 1.25 & $1.06^{\mathrm{b}}$ & $1.11^{\mathrm{Y}}$ & $1.40^{\mathrm{aX}}$ & 0.13 & 0.381 & 0.627 & 0.031 \\
\hline Phase 2 (d 7 to 21$)$ & 0.82 & 0.81 & 0.83 & 0.81 & 0.03 & 0.963 & 0.593 & 0.825 \\
\hline d 7 to 14 & 0.83 & 0.82 & 0.87 & 0.87 & 0.04 & 0.057 & 0.882 & 0.726 \\
\hline d 14 to 21 & 0.81 & 0.80 & 0.79 & 0.75 & 0.05 & 0.425 & 0.557 & 0.776 \\
\hline Phase 3 (d 21 to 36$)$ & 0.72 & 0.70 & 0.70 & 0.68 & 0.02 & 0.283 & 0.164 & 0.996 \\
\hline d 21 to 28 & 0.75 & 0.71 & 0.73 & 0.72 & 0.02 & 0.842 & 0.284 & 0.368 \\
\hline d 28 to 36 & 0.70 & 0.69 & 0.69 & 0.65 & 0.03 & 0.253 & 0.286 & 0.616 \\
\hline Overall ( $\mathrm{d} 0$ to 36$)$ & 0.79 & 0.76 & 0.77 & 0.76 & 0.02 & 0.296 & 0.056 & 0.507 \\
\hline
\end{tabular}

There was no animal mortality during the experimental period. ${ }^{1} \mathrm{HM}$ has $1.0 \mu \mathrm{g} / \mathrm{kg}$ of aflatoxin B1 (AFB1) and $2258 \mu \mathrm{g} / \mathrm{kg}$ of deoxynivalenol (DON) on average for phases 1 and 2, and $44.6 \mu \mathrm{g} / \mathrm{kg}$ of AFB1 and $4635 \mu \mathrm{g} / \mathrm{kg}$ of DON for phase 3. a,b Means with different superscripts differ $(p<0.05)$. ${ }^{X, Y}$ Means with different superscripts tend to differ $(0.05 \leq p<0.10)$.

Feeding HM reduced $(p<0.05)$ blood serum protein, albumin, and creatinine concentrations on day 35 (Table 2). Feeding diets with PYCW tended to decrease aspartate aminotransferase (AST; $p=0.051$ ) and creatine phosphokinase (CPK; $p=0.052)$ concentrations, and blood urea nitrogen $(\mathrm{BUN}) /$ creatinine proportion $(p=0.088)$ in blood serum. Feeding diets with PYCW reduced $(p<0.05)$ the proportion of AST/ALT (alanine aminotransferase) and increased $(p<0.05)$ glucose concentration in blood serum of pigs. There was an interaction $(p<0.05)$ for phosphorus concentration in blood serum of pigs, indicating that when there is no PYCW, HM reduced $(p<0.05)$ phosphorus concentration. The interaction also indicates that in MT, the addition of PYCW tended to increase $(p=0.063)$ phosphorus in serum.

Table 2. Serum variables observed for serum biochemistry, and electrolytes in newly-weaned pigs fed diets high (HM) or low (LM) in mycotoxins ${ }^{1}$ or postbiotic yeast cell wall-based blend (PYCW) for 35 days.

\begin{tabular}{|c|c|c|c|c|c|c|c|c|}
\hline \multirow{2}{*}{$\begin{array}{l}\text { Diet } \\
\text { PYCW }\end{array}$} & \multicolumn{2}{|c|}{$\mathbf{L M}$} & \multicolumn{2}{|c|}{ HM } & \multirow{2}{*}{ SEM } & \multicolumn{3}{|c|}{$p$ Value } \\
\hline & $0 \%$ & $0.2 \%$ & $0 \%$ & $0.2 \%$ & & Diet & PYCW & Diet vs. PYCW \\
\hline Total protein, g/dL & 5.24 & 5.26 & 4.91 & 4.98 & 0.15 & 0.001 & 0.602 & 0.742 \\
\hline Albumin, $\mathrm{g} / \mathrm{dL}$ & 3.54 & 3.51 & 3.23 & 3.33 & 0.13 & 0.009 & 0.745 & 0.489 \\
\hline Globulin, g/dL & 1.70 & 1.75 & 1.68 & 1.66 & 0.14 & 0.367 & 0.796 & 0.605 \\
\hline Albumin/Globulin & 2.14 & 2.05 & 2.00 & 2.06 & 0.22 & 0.561 & 0.884 & 0.513 \\
\hline
\end{tabular}


Table 2. Cont.

\begin{tabular}{|c|c|c|c|c|c|c|c|c|}
\hline \multirow{2}{*}{$\begin{array}{l}\text { Diet } \\
\text { PYCW }\end{array}$} & \multicolumn{2}{|c|}{ LM } & \multicolumn{2}{|c|}{ HM } & \multirow{2}{*}{ SEM } & \multicolumn{3}{|c|}{$p$ Value } \\
\hline & $0 \%$ & $0.2 \%$ & $0 \%$ & $0.2 \%$ & & Diet & PYCW & Diet vs. PYCW \\
\hline AST, IU/L & 37.3 & 32.6 & 43.1 & 29.3 & 5.7 & 0.787 & 0.051 & 0.334 \\
\hline ALT, IU/L & 28.1 & 29.3 & 25.8 & 25.3 & 1.7 & 0.050 & 0.833 & 0.562 \\
\hline AST/ALT & 1.33 & 1.14 & 1.68 & 1.19 & 0.22 & 0.225 & 0.046 & 0.370 \\
\hline ALP, IU/L & 262 & 246 & 249 & 229 & 22 & 0.430 & 0.346 & 0.940 \\
\hline CPK, IU/L & 5107 & 2156 & 4330 & 2203 & 1315 & 0.775 & 0.052 & 0.747 \\
\hline Cholesterol, mg/dL & 94.3 & 88.5 & 84.4 & 85.4 & 3.6 & 0.077 & 0.508 & 0.349 \\
\hline BUN, mg/dL & 14.3 & 13.3 & 14.1 & 13.2 & 0.7 & 0.796 & 0.126 & 0.897 \\
\hline Creatinine, mg/dL & 1.02 & 0.99 & 0.90 & 0.96 & 0.04 & 0.035 & 0.630 & 0.232 \\
\hline BUN/Creatinine & 14.4 & 13.6 & 16.2 & 13.8 & 1.1 & 0.276 & 0.088 & 0.413 \\
\hline Glucose, mg/dL & 106 & 111 & 103 & 109 & 2 & 0.193 & 0.015 & 0.829 \\
\hline Phosphorus, mg/dL & $11.4^{\mathrm{a}}$ & 11.0 & $10.3^{b X}$ & $11.0^{\mathrm{Y}}$ & 0.4 & 0.019 & 0.612 & 0.034 \\
\hline Calcium, mg/dL & 11.1 & 11.0 & 10.8 & 11.0 & 0.2 & 0.182 & 0.787 & 0.334 \\
\hline Sodium, $\mathrm{mEq} / \mathrm{L}$ & 148.7 & 146.9 & 149.8 & 146.0 & 1.9 & 0.964 & 0.145 & 0.592 \\
\hline Potassium, mEq/L & 5.83 & 5.64 & 5.81 & 6.05 & 0.22 & 0.370 & 0.893 & 0.332 \\
\hline $\mathrm{Na} / \mathrm{K}$ & 26.0 & 26.4 & 26.1 & 24.6 & 0.9 & 0.308 & 0.526 & 0.264 \\
\hline Chloride, $\mathrm{mEq} / \mathrm{L}$ & 104.8 & 104.3 & 106.8 & 105.0 & 1.2 & 0.192 & 0.252 & 0.565 \\
\hline
\end{tabular}

${ }^{1} \mathrm{HM}$ has $1.0 \mu \mathrm{g} / \mathrm{kg}$ of AFB1 and $2258 \mu \mathrm{g} / \mathrm{kg}$ of DON on average for phases 1 and 2 , and $44.6 \mu \mathrm{g} / \mathrm{kg}$ of AFB1 and $4635 \mu \mathrm{g} / \mathrm{kg}$ of DON for phase 3. AST, aspartate aminotransferase; ALT, alanine aminotransferase; ALP, alkaline phosphatase; BUN, blood urea nitrogen; CPK, creatine phosphokinase. ${ }^{a, b}$ Means with different superscripts differ $(p<0.05) .{ }^{X, Y}$ Means with different superscripts tend to differ $(0.05 \leq p<0.10)$.

There were no differences for protein carbonyl, malondialdehyde, total glutathione, tumor necrosis factor-alpha (TNF- $\alpha$ ), immunoglobulin A (IgA), immunoglobulin G (IgG), or interleukin 8 (IL-8) in jejunal mucosa among pigs from experimental groups (Table 3 ).

Table 3. Immune and oxidative stress markers from gut mucosa in newly-weaned pigs fed diets high (HM) or low (LM) in mycotoxins ${ }^{1}$ or postbiotic yeast cell wall-based blend (PYCW) for 36 days.

\begin{tabular}{|c|c|c|c|c|c|c|c|c|}
\hline \multirow{2}{*}{$\begin{array}{l}\text { Diet } \\
\text { PYCW }\end{array}$} & \multicolumn{2}{|c|}{ LM } & \multicolumn{2}{|c|}{ HM } & \multirow{2}{*}{ SEM } & \multicolumn{3}{|c|}{$p$ Value } \\
\hline & $0 \%$ & $0.2 \%$ & $0 \%$ & $0.2 \%$ & & Diet & PYCW & Diet vs. PYCW \\
\hline \multicolumn{9}{|c|}{ Concentration/mg of protein } \\
\hline Protein carbonyl, mMol & 2.41 & 2.26 & 1.97 & 2.14 & 0.30 & 0.206 & 0.999 & 0.416 \\
\hline Malondialdehyde, $\mu \mathrm{M}$ & 0.382 & 0.288 & 0.349 & 0.350 & 0.105 & 0.845 & 0.536 & 0.523 \\
\hline Total glutathione, $\mu \mathrm{M}$ & 3.02 & 4.45 & 4.58 & 3.74 & 1.49 & 0.691 & 0.784 & 0.291 \\
\hline TNF- $\alpha, p g$ & 4.53 & 3.86 & 4.45 & 5.49 & 1.19 & 0.501 & 0.870 & 0.458 \\
\hline TNF- $\alpha / \operatorname{IgA}$ & 3.20 & 2.32 & 3.77 & 2.50 & 0.93 & 0.534 & 0.084 & 0.753 \\
\hline $\operatorname{IgA}, \mu \mathrm{g}$ & 2.44 & 2.15 & 1.45 & 2.87 & 0.74 & 0.804 & 0.281 & 0.108 \\
\hline $\mathrm{IgG}, \mu \mathrm{g}$ & 1.36 & 1.48 & 1.25 & 1.46 & 0.31 & 0.815 & 0.540 & 0.885 \\
\hline IL-8, ng & 0.255 & 0.215 & 0.207 & 0.270 & 0.071 & 0.949 & 0.825 & 0.299 \\
\hline
\end{tabular}

${ }^{1} \mathrm{HM}$ has $1.0 \mu \mathrm{g} / \mathrm{kg}$ of AFB1 and $2258 \mu \mathrm{g} / \mathrm{kg}$ of DON on average for phases 1 and 2 , and $44.6 \mu \mathrm{g} / \mathrm{kg}$ of AFB1 and $4635 \mu \mathrm{g} / \mathrm{kg}$ of DON for phase 3. TNF- $\alpha$, tumor necrosis factor-alpha; IL-8, interleukin 8; IgA, immunoglobulin A; IgG, immunoglobulin G.

There were significant interactions for apparent ileal digestibility of dry matter $(p<0.05)$, gross energy $(p<0.05)$, and nitrogen $(p<0.05)$ among pigs from experimental groups (Table 4$)$. These interactions indicate that when there is no PYCW, HM reduced $(p<0.05)$ the apparent ileal digestibility of dry matter, gross energy, and nitrogen. The interactions also indicate that within pigs fed LM, the addition of PYCW decreased $(p<0.05)$ the apparent ileal digestibility of dry matter, gross energy, and nitrogen. Feeding HM also decreased $(p<0.05)$ the apparent ileal digestibility of ether extract. 
Table 4. Apparent ileal digestibility of dry matter, gross energy, nitrogen, and ether extract in diets high (HM) or low (LM) in mycotoxins ${ }^{1}$ or postbiotic yeast cell wall-based blend (PYCW) fed to newly-weaned pigs for 36 days.

\begin{tabular}{|c|c|c|c|c|c|c|c|c|}
\hline \multirow{2}{*}{$\begin{array}{l}\text { Diet } \\
\text { PYCW }\end{array}$} & \multicolumn{2}{|c|}{ LM } & \multicolumn{2}{|c|}{ HM } & \multirow{2}{*}{ SEM } & \multicolumn{3}{|c|}{$p$ Value } \\
\hline & $0 \%$ & $0.2 \%$ & $0 \%$ & $0.2 \%$ & & Diet & PYCW & Diet vs. PYCW \\
\hline Dry matter, $\%$ & $66.5^{a x}$ & $55.9 \mathrm{y}$ & $53.4^{b}$ & 53.7 & 2.2 & 0.001 & 0.023 & 0.018 \\
\hline Gross energy, \% & $70.0^{a x}$ & $59.4^{\mathrm{y}}$ & $56.6^{b}$ & 56.6 & 2.0 & $<0.001$ & 0.011 & 0.011 \\
\hline Nitrogen, $\%$ & $80.4^{\mathrm{ax}}$ & 74.9 y & $72.6^{b}$ & 74.1 & 1.1 & $<0.001$ & 0.065 & 0.002 \\
\hline Ether extract, \% & 98.2 & 97.6 & 97.1 & 96.7 & 0.4 & 0.009 & 0.179 & 0.888 \\
\hline
\end{tabular}

${ }^{1} \mathrm{HM}$ has $1.0 \mu \mathrm{g} / \mathrm{kg}$ of AFB1 and $2258 \mu \mathrm{g} / \mathrm{kg}$ of DON on average for phases 1 and 2, and $44.6 \mu \mathrm{g} / \mathrm{kg}$ of AFB1 and $4635 \mu \mathrm{g} / \mathrm{kg}$ of DON for phase 3. ${ }^{\mathrm{a}, \mathrm{b}}$ Means with different superscripts differ $(p<0.05)$. ${ }^{\mathrm{x}, \mathrm{y}}$ Means with different superscripts differ $(p<0.05)$

In addition, feeding HM decreased $(p<0.05)$ crypt depth from mid jejunum, but no other differences were observed for intestinal histomorphology on villus width, villus height to crypt depth ratio, nor on proportion of Ki-67-positive cells (Table 5).

Table 5. Intestinal morphology and Ki-67 ${ }^{1}$ proportion in histology sections of mid jejunum in newly-weaned pigs fed diets high (HM) or low (LM) in mycotoxins ${ }^{2}$ or postbiotic yeast cell wall-based blend (PYCW) for 36 days.

\begin{tabular}{|c|c|c|c|c|c|c|c|c|}
\hline \multirow{2}{*}{$\begin{array}{l}\text { Diet } \\
\text { PYCW }\end{array}$} & \multicolumn{2}{|c|}{ LM } & \multicolumn{2}{|c|}{ HM } & \multirow{2}{*}{ SEM } & \multicolumn{3}{|c|}{$p$ Value } \\
\hline & $0 \%$ & $0.2 \%$ & $0 \%$ & $0.2 \%$ & & Diet & PYCW & Diet vs. PYCW \\
\hline Villus width, $\mu \mathrm{m}$ & 420.9 & 432.4 & 401.9 & 407.7 & 7.1 & 0.263 & 0.684 & 0.611 \\
\hline Villus height $(\mathrm{V}), \mu \mathrm{m}$ & 153.2 & 157.7 & 161.2 & 160.7 & 19.8 & 0.100 & 0.512 & 0.826 \\
\hline Crypt depth (C), $\mu \mathrm{m}$ & 214.0 & 223.4 & 203.4 & 203.5 & 11.6 & 0.045 & 0.522 & 0.527 \\
\hline $\mathrm{V}: \mathrm{C}$ & 2.00 & 1.97 & 2.02 & 2.04 & 0.14 & 0.651 & 0.932 & 0.785 \\
\hline Ki-67 proportion, \% & 25.93 & 25.61 & 27.27 & 27.44 & 2.40 & 0.343 & 0.963 & 0.882 \\
\hline
\end{tabular}

${ }^{1} \mathrm{Ki}-67$ is an estimate of the proliferative rate, calculated based on the proportion of cells positive to Ki-67 staining (immunohistochemistry) to the total number of cells in the crypt. ${ }^{2} \mathrm{HM}$ has $1.0 \mu \mathrm{g} / \mathrm{kg}$ of AFB1 and $2258 \mu \mathrm{g} / \mathrm{kg}$ of DON on average for phases 1 and 2, and $44.6 \mu \mathrm{g} / \mathrm{kg}$ of AFB1 and $4635 \mu \mathrm{g} / \mathrm{kg}$ of DON for phase 3.

\section{Discussion}

Considering that naturally contaminated feedstuffs were used for diet formulation, a myriad of mycotoxins were detected, suggesting contamination of multiple fungi. Mycotoxin-contaminated corn was added only to the phase 3 diet to model a real scenario in a commercial farm, where pigs may be fed diets with higher mycotoxin levels as they get older. Such a scenario may happen as older pigs are less susceptible to mycotoxins [27] and, thus, feedstuffs potentially contaminated with mycotoxins may be fed to older pigs. The overall concentration of mycotoxins was three-fold higher in HM than in LM diets, aiming to exceed the guidance levels of mycotoxins' (AFB1 and DON) concentration in the United States (20 and $1000 \mu \mathrm{g} / \mathrm{kg}$, [11,13]) and Europe (10 and $900 \mu \mathrm{g} / \mathrm{kg}$, [12,14]) and cause detrimental effects by feeding HM diet to pigs. The advisory levels of DON for swine are $5000 \mu \mathrm{g} / \mathrm{kg}$ in grain, with grain feedstuffs not to exceed $20 \%$ of the final diet [28]. This would result in a concentration of $1000 \mu \mathrm{g} / \mathrm{kg}$ of the final diet. As intended in the current study, aflatoxins and DON concentrations in HM surpassed the values preconized for feeding nursery pigs in the United States. In phases 1 and 2, both LM and HM diets were below $(1.0 \mu \mathrm{g} / \mathrm{kg})$ the threshold for AFB1, whereas in phase 3, HM diet was above the threshold $(44.6 \mu \mathrm{g} / \mathrm{kg})$. For DON in phases 1 and 2 , HM diet was above $(2258 \mu \mathrm{g} / \mathrm{kg})$ the threshold for the mycotoxin. During phase 3, both LM and HM diets were above (1311 vs. $4635 \mu \mathrm{g} / \mathrm{kg}$ ) the threshold for DON. A lower percentage of DON contaminated DDGS was used on phase $3(20.8 \%)$ in comparison to phases 1 and $2(22 \%)$. However, the supplemental mycotoxin (difference between LM and HM) was achieved as intended (supplemental $2000 \mu \mathrm{g}$ of DON per $\mathrm{kg}$ of feed) in the current study (supplemental $2163 \mu \mathrm{g}$ of DON per $\mathrm{kg}$ of feed). 
The levels of DON in the current study are considered as the sum of DON and its acetylated and glycosylated forms. Even though the DON-3-glucoside does not seem to have detrimental effects [29] this choice was based on the previously proven ability of the gut microbiome to convert DON-3-glucoside into the toxic form (DON) both in vitro [30] and in vivo [31] in pigs. Regarding the acetylated forms, they may show either less, similar, or more adverse effects than DON [29,32]. Comparable to DON-3-glucoside, 3-acetyl-DON and 15-acetyl-DON can be converted to DON and, thus, were considered together to have similar effects as DON [33]. Nivalenol is also a type B trichothecene, but its conversion to DON has not been documented. Besides, nivalenol presents stronger harmful effects than DON [32,34] and, thus, is considered as a distinct mycotoxin in the current as well as in other scientific publications [35].

Zearalenone average concentration in LM and HM diets (44.3 and $96.0 \mu \mathrm{g} / \mathrm{kg}$ of feed) did not surpass the guidance level of $100 \mu \mathrm{g} / \mathrm{kg}$ preconized in Europe [14] for young pigs. Indeed, previous studies show that zearalenone in this range would not affect health and growth of pigs at 7 to $30 \mathrm{~kg}$ body weight [35-38]. There are no regulations concerning zearalenone concentration in swine feed in the United States. The sum of fumonisins B1, B2, and B3 observed in the current study did not surpass the recommended maximum level set by the Food and Drug Administration [13] of 10,000 $\mu \mathrm{g} / \mathrm{kg}$ for pigs. Similarly, the sum of fumonisins B1 and B2 detected in diets was below the guidance level of $5000 \mu \mathrm{g} / \mathrm{kg}$ recommended for pigs in Europe [14]. Considering the low level of contamination of zearalenone and fumonisins, their impacts on health and growth of pigs in this study would be insignificant and, therefore, are not discussed further.

In the present study, it was observed that feeding HM (aflatoxins at $1.0 \mu \mathrm{g} / \mathrm{kg}$ of feed and DON at $2094 \mu \mathrm{g} / \mathrm{kg}$ of feed) caused reduced feed intake in newly-weaned pigs during phase 1 . For phases 2 and 3, AFB1 (1.0 and $44.6 \mu \mathrm{g} / \mathrm{kg}$ ) and DON (2421 and $4635 \mu \mathrm{g} / \mathrm{kg}$ ) levels were higher and reduced feed intake. In high and acute doses, deoxynivalenol is known to cause vomiting and impair feed intake [36]. In low and chronic doses, deoxynivalenol depresses feed intake, especially in pigs, due to reduced peristalsis mediated by local serotonin $[37,38]$ and satiety signaling mediated by peptide $Y Y$ (peptide tyrosine tyrosine) [39] along with the release of pro-inflammatory cytokines [40,41]. Aflatoxins also modulate cytokine expression by reducing IL-1 $\beta$ and increasing IL-10 [42] and TNF- $\alpha$ when in combination with DON [7]. In a study performed with mice, DON depressed feed intake as early as $2 \mathrm{~h}$ after the ingestion in a dose-response manner [39]. The mechanism underlying feed refusal is related to the increase in peptide YY and serotonin plasma levels, leading to satiety perception, as shown in a previous study [43]. The lower energy and nutrient intake, negatively impacted by HM after phase 1, led to impaired animal growth during the entire period, as observed in ADG. Our study is in accordance with results obtained by Chaytor et al. [7], where AFB1 and DON could impair animal growth at 60 and $300 \mu \mathrm{g} / \mathrm{kg}$ of feed, respectively. Current results are supported by our outcomes observed for gross energy and nitrogen apparent ileal digestibility, where feeding HM reduced the digestibility when no PYCW was added. It was previously shown that DON at $10,000 \mu \mathrm{g} / \mathrm{kg}$ of feed is able to reduce digestibility of essential amino acids in pigs [44]. Similarly, the current study illustrates that, by the end of phase three, pigs fed HM (DON at $4635 \mu \mathrm{g} / \mathrm{kg}$ and AFB1 at $44.6 \mu \mathrm{g} / \mathrm{kg}$ of feed) showed impaired energy and nitrogen apparent ileal digestibility in comparison to pigs fed LM (DON at $1311 \mu \mathrm{g} / \mathrm{kg}$ of feed).

Comparing growth performance for phases 1, 2 and 3, feeding HM reduced ADG by 22, 15, and $14 \%$, and ADFI was reduced by 22,15 and $12 \%$, respectively. This result suggests that HM effects were stronger during phase 1 , while animals were recovering from weaning stress [45]. The interaction in ADG during phase 1 shows that feeding diets with mycotoxins decreased pig ADG when the PYCW was not added to diets. Of interest, when PYCW was added, feeding HM did not reduce ADG during phase 1. At the same time, the interaction in $\mathrm{G} / \mathrm{F}$ shows that pigs fed $\mathrm{HM}$ had greater $\mathrm{G} / \mathrm{F}$ when PYCW was included. Indeed, PYCW tended to improve G/F among pigs fed MT, indicating that PYCW provided improved growth performance in challenged pigs. During the first week of phase 2, animals fed HM showed greater G/F probably due to its lower ADFI (on average $116 \mathrm{~g}$ lower). This is 
a result of an evolutional adaptation, where pigs eating reduced amounts of energy and nutrient have a compensatory improvement in feed efficiency [46]. In the overall period, adding PYCW tended to reduce $\mathrm{G} / \mathrm{F}$, and such decrease in efficiency was supported by the reduction of gross energy and nitrogen apparent ileal digestibility when adding PYCW to LM.

It was not possible to distinguish if the inclusion of AFB1-contaminated corn in phase 3 diet solely influenced the variables tested or if AFB1 inclusion showed additive or synergistic activity that could eventually potentialize one or other deleterious effects of mycotoxins. Comparing growth performance for phase 2 and phase 3, the difference between animals fed LM and animals fed HM was similar for ADG (15 and 14\%), but the difference widens for ADFI (15 and 12\%), and G/F (-1\% and $3 \%$ ). The observed outcomes are likely to be related to characteristics of each group in the beginning of phase 3, instead of AFB1 addition. The lower body weight of pigs from the mycotoxin group, respectively 9 and 11\% lower for phase 2 and phase 3, may have influenced such results, as animals with a smaller body size need less energy and nutrients for maintenance and, thus, can direct these for tissue deposition [47].

Besides the aforementioned effects on pig growth, DON can debilitate liver and kidney function $[48,49]$. In addition, AFB1 has also shown deleterious effects upon liver and mineral balance in pigs [50]. Weaver et al. [8] has revealed that the combination of AFB1 and DON (AFB1 at 150 and DON at $1100 \mu \mathrm{g} / \mathrm{kg}$ of feed) caused liver damage. In the current study, feeding HM reduced albumin and total protein concentration in serum, which may indicate that liver protein synthesis was compromised due to mycotoxin toxicity [51]. Aflatoxins are known to impair cell protein synthesis through inhibition of RNA polymerase activity in the nucleus [52], resulting in reduced cell viability [53]. Taken together, aflatoxin effects could be responsible for the hypoproteinemia observed as well as impaired pig growth. Mycotoxins tended to decrease the ALT, a cytosolic enzyme investigated to assess liver and kidney functions [54]. Even though an increase in ALT would be expected, cases of chronic liver damage are associated with the reduction in serum levels of the enzyme [55], as observed in the current study. The assumption of liver damage is supported by the tendency to decreased concentrations of cholesterol in pigs fed diets with mycotoxins, as cholesterol is mainly synthetized by hepatocytes [56]. An increase in creatinine level in serum is observed in the case of liver failure [57,58], but, unexpectedly, a decrease in serum creatinine in pigs fed diets with mycotoxins was observed in the current study. Creatinine level in serum linearly increases with pig body weight [59], thus, this could be the reason for the higher creatinine level observed in the group fed LM, which was $3.36 \mathrm{~kg}$ heavier at $\mathrm{d} 36$ than pigs fed HM. However, considering there were no changes in BUN, BUN/creatinine, or alkaline phosphatase ratio in animals consuming mycotoxins, it is possible to infer that liver function was not greatly affected in the impairment of nitrogen excretion [60-62]. The CPK increase in serum can be indicative of severe hepatic [63] or muscular damage [64]. Hence, the tendency for decreased CPK, and reduced AST and AST/ALT promoted by PYCW suggest that the addition of PYCW may have induced a protective effect in the liver and muscle, reducing the release of their enzymes in serum. The relative level between AST and ALT can be a more reliable variable to evaluate chronic liver damage in humans [65]. Such correlation indicating liver damage can also be observed in pigs challenged with bacterial toxin [66] and under mycotoxin challenge [67]. Furthermore, stimulation of protein synthesis and proliferation in muscular cells proportioned by n-butyric acid [68], one of the components in PYCW, could have mitigated the muscular damage caused by mycotoxins.

The reduction in BUN/creatinine along with the increase in glucose suggest that animals fed PYCW could more efficiently utilize protein and carbohydrate sources in feed. Indeed, yeast cell wall supplementation above $0.05 \%$ has been shown to play a role in modulating amino acid and glucose levels in blood serum of pigs [69]. Mycotoxins decreased phosphorus levels in serum of animals in the absence of PYCW, but the addition of PYCW mitigated the deleterious effects of mycotoxins on phosphorus levels in pigs fed HM. Mycotoxin damage to kidney and liver [48,70] may have caused the alteration in phosphorus levels, considering that the liver is the main site for cholesterol synthesis, vitamin D precursor, and that both organs are essential for vitamin D activation [71,72]. Reinforcing 
this line of thought, and as aforementioned, mycotoxins in fact decreased cholesterol level in serum of pigs fed diets with mycotoxins. In addition, previous data have shown toxic effects of aflatoxin on kidney, calcium and vitamin D metabolism in broilers [73]. The PYCW was able to mitigate mycotoxic effects on phosphorus balance, as seen by the tendency towards increased phosphorus levels in serum of pigs fed diets with mycotoxins. However, further investigation into vitamin D levels as well as kidney and liver function would be necessary to determine if the decrease in phosphorus was related to vitamin D metabolism observed in the current study. Of interest, one of the components of PYCW is vitamin $C$. The vitamin $C$ pool can be depleted under challenging situations as it is involved in the reduction of oxidative stress [74]. Furthermore, vitamin C supplementation in weaned pigs is related to improved immune function [75].

Pigs challenged with DON have shown an increase in inflammatory cytokine expression as IL-8, as well as up-regulation of glutathione peroxidase 2 gene and IgG [76]. In the present study, impacts of mycotoxins were not strong enough to affect oxidative damage markers, pro-inflammatory cytokines, or immunoglobulins in the jejunal mucosa. In a previous study conducted by Pasternak et al. [77], where pigs chronically exposed to DON $(3800 \mu \mathrm{g} / \mathrm{kg}$ of feed vs. $4635 \mu \mathrm{g} / \mathrm{kg}$ of feed in the current study), IL-8 in the ileum was the only cytokine upon which effects of mycotoxin presented a trend to increase. Thus, the relative low mycotoxin level used seemed unlikely to promote changes in immunological variables.

It was possible to observe that ileal apparent digestibility for gross energy and nitrogen were reduced when adding PYCW to LM. Yeast cell wall is mostly composed of $\beta$-D-glucans and mannose-oligosaccharides; the latter has been shown to improve nutrient digestibility when supplemented in a concentrated form from 0.1 to $0.2 \%$ in diets [78] with the effect being more pronounced during the first two weeks after weaning [79]. The $\beta$-glucans have shown to improve nutrient digestibility in weaned pigs when treated with antibiotics [80]. In the current study, however, there was a lack of difference in nutrient digestibility when adding PYCW in pigs fed HM. Alternatively, the current reduction in apparent ileal digestibility of nutrients in feed observed in pigs fed LM with PYCW could be due to reduced digestibility of $\beta$-D-glucans derived from yeast non-starch polysaccharides [81].

The decrease in crypt depth was the only noticeable effect in animals consuming mycotoxins. DON might have impaired cell proliferation in the crypts by inhibiting the Wnt/ $\beta$-catenin pathway [82]. Nivalenol has shown greater impact in jejunal morphology than DON [34] and the ileum is the most affected segment of the small intestine regarding protein synthesis [76,83], which may explain why no major effects on gut morphology were detected.

Chronic mycotoxin challenge with DON (3050 $\mu \mathrm{g} / \mathrm{kg}$, for 7 to $25 \mathrm{~kg}$ body weight) and AFB1 (44.6 $\mathrm{\mu g} / \mathrm{kg}$, for 16 to $25 \mathrm{~kg}$ body weight) clearly impaired growth performance, reduced apparent ileal digestibility of nutrients in feeds, and caused mild liver damage in newly-weaned pigs. The postbiotic yeast cell wall-based blend partly reduced liver damage. In pigs not challenged with mycotoxins, the postbiotic yeast cell wall-based blend reduced apparent ileal digestibility of dry matter, gross energy, and nitrogen; whereas in pigs challenged with mycotoxins, the postbiotic yeast cell wall-based blend maintained growth performance and apparent ileal digestibility of all nutrients in feeds.

\section{Conclusions}

Chronic dietary challenge of DON $(3050 \mu \mathrm{g} / \mathrm{kg})$ and AFB1 $(44.6 \mu \mathrm{g} / \mathrm{kg})$ is harmful to newly-weaned pigs, compromising growth and nutrient digestibility. Supplementation with the postbiotic yeast cell wall-based blend could partially overcome the harmful effects of the dietary challenge of multiple mycotoxins on growth and health of weanling pigs.

\section{Materials and Methods}

The Institutional Animal Care and Use Committee (IACUC) at North Carolina State University (Raleigh, NC, USA) reviewed and approved the protocol of this experiment. 


\subsection{Animals and Experimental Diets}

The levels of selected mycotoxins detected in conventional corn DDGS, DON-contaminated DDGS, and aflatoxin-contaminated corn used for diet formulation are presented on Table 6.

Table 6. Selected mycotoxins detected in conventional dried distillers grains with solubles (DDGS), deoxynivalenol (DON) contaminated DDGS, and aflatoxin (AF) contaminated corn used for diet formulation to newly-weaned pigs for $36 \mathrm{~d}$.

\begin{tabular}{lccc}
\hline Mycotoxin, $\boldsymbol{\mu g} / \mathbf{k g}$ & Conventional DDGS & DON DDGS & AF Corn \\
\hline Aflatoxin B1 & 0.1 & 0.1 & 239.6 \\
Aflatoxin B2 & 0.5 & 0.5 & 30.9 \\
Aflatoxin G1 & 0.1 & 0.1 & 14.8 \\
Aflatoxin G2 & 0.1 & 0.1 & 0.1 \\
Deoxynivalenol & 2064 & 5897 & 4 \\
3-acetyl-deoxynivalenol & 21.7 & 102.9 & 2.3 \\
15-acetyl-deoxynivalenol & 550 & 2104 & 2 \\
Deoxynivalenol-3-glucoside & 38.7 & 11.0 & 11.0 \\
Nivalenol & 49.9 & 49.9 & 49.9 \\
Fusarenon-X & 2.5 & 2.5 & 2.5 \\
Fumonisin B1 & 479 & 347 & 29,773 \\
Fumonisin B2 & 27 & 37 & 5478 \\
Fumonisin B3 & 5 & 17 & 6092 \\
Zearalenone & 213 & 1720 & 3 \\
\hline
\end{tabular}

Mycotoxin concentrations were measured at the Analytical Services Laboratory of Alltech Inc. Laboratory (37+ $+^{\mathrm{TM}}$, Alltech Inc., Nicholasville, KY, USA). The detection limit was used for variables not detected. Levels of mycotoxins reported considered values above the limit of quantitation of each mycotoxin, the relative standard deviation $(<20 \%)$, and the signal to noise ratio $(>10)$.

Experimental diets were formulated to meet or exceed the nutrient requirements suggested by the National Research Council (NRC) [84] following a three-phase feeding program (Table 7). The use of three dietary phases followed the recommendation of the NRC to meet nutritional requirements of nursery pigs [84]. All experimental diets were sampled (from nine different locations, $2 \mathrm{~kg}$ total per diet), with $200 \mathrm{~g}$ of each being sent to North Carolina Department of Agriculture (Raleigh, NC, USA) and to the Analytical Services Laboratory of Alltech Inc. (37+ ${ }^{\mathrm{TM}}$, ISO/IEC 17025:2005 official accreditation (No. 79481) using LC-MS/MS; Alltech Inc., Nicholasville, KY, USA) for analyses of nutrient composition and mycotoxin concentration, respectively (Table 8). The sample processing for quantitative determination of mycotoxin concentration followed the procedures previously described by Jackson et al. [85]. In short, ground and homogenized feed samples had $400 \mathrm{mg}$ subsampled and placed in silanized glass vials for extraction with acetonitrile/water/formic acid (84.0:15.9:0.1, v/v/v) during $18 \mathrm{~h}$. Vials were centrifuged and the supernatant was dried at room temperature for $30 \mathrm{~min}$ under nitrogen stream. A mixture of water/acetonitrile/formic acid (95.0:4.9:0.1, v/v/v) with $10 \mathrm{mmol} / \mathrm{L}$ of ammonium acetate was used as loading buffer for analysis of 44 mycotoxins by LC-MS/MS.

Table 7. Composition of experimental diets high (HM) or low (LM) in mycotoxins in a three-phase feeding program fed to newly-weaned pig for $36 \mathrm{~d}^{1}$.

\begin{tabular}{lcccccc}
\hline \multirow{2}{*}{ Item } & \multicolumn{2}{c}{ Phase 1 (d 0 to 7) } & \multicolumn{2}{c}{ Phase 2 (d 7 to 21) } & \multicolumn{2}{c}{ Phase 3 (d 21 to 36) } \\
\cline { 2 - 7 } & LM & HM & LM & HM & LM & HM \\
\hline Ingredient, \% & & & & & & \\
Ground corn & 14.67 & 14.67 & 31.07 & 31.07 & 45.80 & 41.05 \\
Aflatoxin corn ${ }^{2}$ & - & - & - & - & - & 4.75 \\
Corn DDGS & $\mathbf{2 2 . 0 0}$ & - & $\mathbf{2 2 . 0 0}$ & - & $\mathbf{2 0 . 8 1}$ & - \\
DON corn DDGS & - & $\mathbf{2 2 . 0 0}$ & - & $\mathbf{2 2 . 0 0}$ & - & $\mathbf{2 0 . 8 1}$ \\
Soybean meal & 16.00 & 16.00 & 19.00 & 19.00 & 28.36 & 28.36 \\
Whey permeate & 20.00 & 20.00 & 10.00 & 10.00 & - & - \\
\hline
\end{tabular}


Table 7. Cont.

\begin{tabular}{lcccccc}
\hline \multirow{2}{*}{ Item } & \multicolumn{2}{c}{ Phase 1 (d 0 to 7) } & \multicolumn{2}{c}{ Phase 2 (d 7 to 21) } & \multicolumn{2}{c}{ Phase 3 (d 21 to 36) } \\
\cline { 2 - 7 } & LM & HM & LM & HM & LM & HM \\
\hline Cookie meal & 10.00 & 10.00 & 5.00 & 5.00 & - & - \\
Poultry meal & 6.00 & 6.00 & 4.00 & 4.00 & - & - \\
Blood plasma & 5.00 & 5.00 & 3.00 & 3.00 & - & - \\
Fish meal & 2.00 & 2.00 & - & - & - & - \\
Poultry fat & 2.00 & 2.00 & 3.00 & 3.00 & 1.90 & 1.90 \\
Limestone & 0.90 & 0.90 & 1.05 & 1.05 & 1.09 & 1.09 \\
Dicalcium phosphate & - & - & 0.50 & 0.50 & 0.76 & 0.76 \\
Salt & 0.22 & 0.22 & 0.22 & 0.22 & 0.21 & 0.21 \\
L-lysine HCl & 0.53 & 0.53 & 0.51 & 0.51 & 0.35 & 0.35 \\
DL-methionine & 0.15 & 0.15 & 0.12 & 0.12 & 0.04 & 0.04 \\
L-threonine & 0.10 & 0.10 & 0.10 & 0.10 & 0.03 & 0.03 \\
Mineral mix & 0.15 & 0.15 & 0.15 & 0.15 & 0.14 & 0.14 \\
Vitamin mix & 0.03 & 0.03 & 0.03 & 0.03 & 0.03 & 0.03 \\
Zinc oxide & 0.25 & 0.25 & 0.25 & 0.25 & - & - \\
Titanium dioxide & - & - & - & - & 0.48 & 0.48 \\
Calculated composition & & & & & & \\
DM, \% & 91.10 & 91.10 & 90.48 & 90.48 & 89.57 & 89.57 \\
ME, kcal/kg & 3471 & 3471 & 3480 & 3480 & 3391 & 3391 \\
SID Lys, \% & 1.50 & 1.50 & 1.35 & 1.35 & 1.23 & 1.23 \\
SID Thr, \% & 0.88 & 0.88 & 0.80 & 0.80 & 0.73 & 0.73 \\
SID Trp, \% & 0.25 & 0.25 & 0.22 & 0.22 & 0.23 & 0.23 \\
SID Met + Cys, \% & 0.82 & 0.82 & 0.74 & 0.74 & 0.68 & 0.68 \\
Ca, \% & 0.85 & 0.85 & 0.80 & 0.80 & 0.71 & 0.71 \\
STTD P, \% & 0.47 & 0.47 & 0.41 & 0.41 & 0.33 & 0.33 \\
DON 4, $\mu$ g/kg & 0 & 2000 & 0 & 2000 & 0 & 2000 \\
AF, $\mu$ g/kg & 0 & 0 & 0 & 0 & 0 & 200 \\
\hline
\end{tabular}

${ }^{1}$ Postbiotic yeast cell wall-based blend (PYCW) was added to LM and HM at $0.2 \%$ in all phases to create two other dietary treatments. ${ }^{2}$ Aflatoxin corn, aflatoxin-contaminated corn (mycotoxin concentration: $285 \mu \mathrm{g} / \mathrm{kg}$ of aflatoxins and $41.3 \mathrm{mg} / \mathrm{kg}$ of feed of fumonisins). ${ }^{3}$ Deoxynivalenol (DON) corn dried distillers grains with solubles (DDGS), deoxynivalenol-contaminated corn DDGS (mycotoxin concentration: $8115 \mu \mathrm{g} / \mathrm{kg}$ of feed of deoxynivalenol and $401 \mu \mathrm{g} / \mathrm{kg}$ of feed of fumonisins). ${ }^{4}$ Deoxynivalenol concentration is reported as sum of deoxynivalenol and its metabolites: 3-acetyl-deoxynivalenol, 15-acetyl-deoxynivalenol, and deoxynivalenol-3-glucoside. Ingredients in bold were included or not (no inclusion is represented by a dash "-_) depending on the dietary treatment. DM, dry matter; ME, metabolizable energy; SID, standard ileal digestibility; and STTD, standard total tract digestibility.

Table 8. Selected mycotoxins detected in diets high (HM) or low (LM) in mycotoxins in a 3-phase feeding program fed to newly-weaned pig for $36 \mathrm{~d}$.

\begin{tabular}{|c|c|c|c|c|c|c|c|}
\hline \multirow{2}{*}{$\begin{array}{l}\text { Mycotoxin, } \\
\mu \mathrm{g} / \mathrm{kg}\end{array}$} & \multirow{2}{*}{$\begin{array}{l}\text { Phase } \\
\text { Diet }^{1}\end{array}$} & \multicolumn{2}{|c|}{1} & \multicolumn{2}{|c|}{2} & \multicolumn{2}{|c|}{3} \\
\hline & & $\mathbf{L M}$ & HM & LM & HM & LM & HM \\
\hline \multicolumn{2}{|l|}{ Aflatoxin B1 } & 0.1 & 0.1 & 0.1 & 0.1 & 0.1 & 43.7 \\
\hline \multicolumn{2}{|l|}{ Aflatoxin B2 } & 0.5 & 0.5 & 0.5 & 0.5 & 0.5 & 0.5 \\
\hline \multicolumn{2}{|l|}{ Aflatoxin G1 } & 0.1 & 0.1 & 0.1 & 0.1 & 0.1 & 0.1 \\
\hline \multicolumn{2}{|l|}{ Aflatoxin G2 } & 0.1 & 0.1 & 0.1 & 0.1 & 0.1 & 0.1 \\
\hline \multicolumn{2}{|c|}{ Deoxynivalenol } & 501 & 1534 & 524 & 1837 & 1050 & 3956 \\
\hline \multicolumn{2}{|c|}{ 3-acetyl-deoxynivalenol } & 2.3 & 28.6 & 2.3 & 29.7 & 2.3 & 25.2 \\
\hline \multicolumn{2}{|c|}{ 15-acetyl-deoxynivalenol } & 145 & 521 & 154 & 543 & 106 & 435 \\
\hline \multicolumn{2}{|c|}{ Deoxynivalenol-3-glucoside } & 11 & 11 & 11 & 11 & 152 & 220 \\
\hline \multicolumn{2}{|l|}{ Nivalenol } & 49.9 & 49.9 & 49.9 & 49.9 & 49.9 & 49.9 \\
\hline \multicolumn{2}{|l|}{ Fusarenon-X } & 2.5 & 2.5 & 2.5 & 2.5 & 2.5 & 2.5 \\
\hline \multicolumn{2}{|l|}{ Fumonisin B1 } & 130 & 156 & 219 & 239 & 53 & 1,289 \\
\hline \multicolumn{2}{|l|}{ Fumonisin B2 } & 40.9 & 41.7 & 39.1 & 19.0 & 1.8 & 67.5 \\
\hline \multicolumn{2}{|l|}{ Fumonisin B3 } & 5.0 & 5.0 & 5.0 & 5.0 & 5.0 & 41.3 \\
\hline \multicolumn{2}{|l|}{ Zearalenone } & 3 & 3 & 128 & 242 & 3 & 43 \\
\hline
\end{tabular}

Mycotoxin concentrations were measured at the Analytical Services Laboratory of Alltech Inc. Laboratory (37+ ${ }^{\mathrm{TM}}$, Alltech Inc., Nicholasville, KY, USA). The detection limit was used for variables not detected. Levels of mycotoxins reported considered values above the limit of quantitation of each mycotoxin, the relative standard deviation $(<20 \%)$, and the signal to noise ratio $(>10) .{ }^{1}$ Postbiotic yeast cell wall-based blend (PYCW) was added to LM and HM at $0.2 \%$ in all phases to create two other dietary treatments at each phase. 
Forty-eight ( 24 barrows and 24 gilts) crossbred pigs (PIC $337 \times$ Camborough 22) were weaned at $21 \mathrm{~d}$ of age $(7.49 \pm 0.11 \mathrm{~kg})$. Subsequent to weaning, pigs were moved to the research farm and allotted to four dietary treatments based on a completely randomized block design according to sex and body weight (heavy, medium, and light) with two factors for 36 days based on a three-phase feeding program. Pigs within the heavy body weight group ranged from 9.12 to $7.68 \mathrm{~kg}$, within the medium body weight group the range was 7.64 to $7.28 \mathrm{~kg}$, and within the light body weight group the range was 7.2 to $6.04 \mathrm{~kg}$. The two factors were: (1) dietary mycotoxins, obtained from naturally contaminated DDGS (DON: 887.3 or $3050 \mu \mathrm{g} / \mathrm{kg}$ of feed during all phases) and corn (AFB1: 1.0 or $44.6 \mu \mathrm{g} / \mathrm{kg}$ of feed during phase 3 ), and (2) PYCW (0 or $0.2 \%$; Alltech Inc., Nicholasville, KY, USA). The PYCW is a proprietary blend of postbiotic functional bioactive constituents containing hydrolyzed yeast cell wall of Saccharomyces cerevisiae, organic acids (n-butyric acid), vitamins (ascorbic acid), and essential oils (rosemary extract, Alltech Inc., Nicholasville, KY, USA). An overview of pig assignment to treatments according to the factors and mycotoxin levels per treatment is detailed in Figure 1.

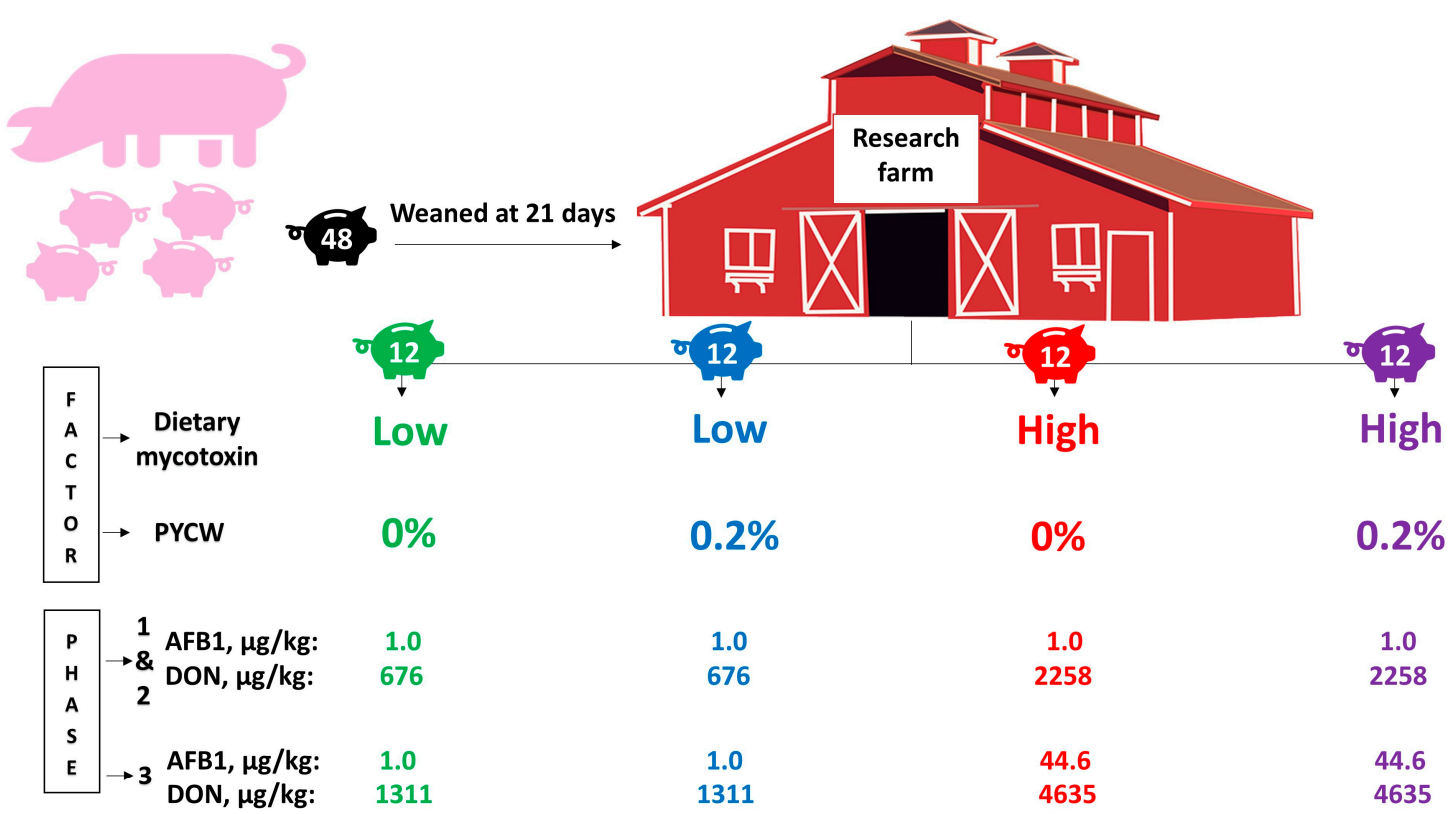

Figure 1. Experimental arrangement and pig assignment to treatments. Forty-eight pigs were weaned at 21 days of age and assigned to four dietary treatments $(n=12)$ following a randomized complete block design in a $2 \times 2$ factorial arrangement. Pigs in green received low mycotoxin diet (LM; formulated without the dietary mycotoxin factor-conventional DDGS and corn); pigs in blue received LM and postbiotic yeast cell wall-based blend (PYCW) at $0.2 \%$; pigs in red received high mycotoxin diet (HM; formulated with dietary mycotoxin factor-DON-contaminated DDGS and, during phase 3, aflatoxin-contaminated corn); and pigs in purple received HM and PYCW at $0.2 \%$. The average aflatoxin B1 (AFB1) and deoxynivalenol (DON) levels during phases 1 and 2, and during phase 3 are specified per treatment.

\subsection{Data Collection}

Body weight of pigs and feed consumption by pigs were recorded weekly and used to obtain average daily gain (ADG), average daily feed intake (ADFI), and gain to feed ratio (G/F). On d 35, $10 \mathrm{~mL}$ blood samples from the external jugular vein were collected with $0.8 \times 32 \mathrm{~mm}$ needles (Eclipse, Becton Dickinson Vacutainer Systems, Franklin Lakes, NJ, USA) and serum blood collection tubes (Becton Dickinson Vacutainer Systems, Franklin Lakes, NJ, USA) using a vacutainer tube holder, following procedures routinely employed by our research group $[20,86,87]$. Serum samples were stored at $-80^{\circ} \mathrm{C}$ in a freezer (812660-760, Thermo Fisher Scientific, Waltham, MA, USA) in $1.5 \mathrm{~mL}$ tubes (Fisherbrand, Fisher Scientific, Hampton, NH, USA) after centrifugation at $1509 \times g$ at $4{ }^{\circ} \mathrm{C}$ 
for 15 min (5811F, Eppendorf, Hamburg, HH, Germany). Serum samples were used for measuring serum biochemistry (including serum proteins, enzymes, cholesterol, blood urea nitrogen, creatinine, and glucose), and electrolyte profiling (Antech Diagnostics Laboratory, Cary, NC, USA).

At the end of the study (d 36), pigs were euthanized to obtain scrapped mucosa and intact tissue from mid-jejunum and ileal digesta. Pigs were stunned by captive bolt followed by vena cava exsanguination. Samples of gut mucosa (from $15 \mathrm{~cm}$ ) from the mid-jejunum were scraped with the aid of clean histological slides. The mid-jejunum of pigs was determined at $3.5 \mathrm{~m}$ distal of the duodenum [88]. Mucosal samples were frozen in liquid nitrogen immediately after collection and then transferred to $-80^{\circ} \mathrm{C}$ until laboratory analyses. Ileal digesta samples were obtained by gently squeezing from the ileocecal junction until the proximal end of the ileocecal fold. Ileal digesta containers were emerged in ice and then stored at $-80^{\circ} \mathrm{C}$ until laboratory analyses. Tissue samples $(5 \mathrm{~cm})$ from the mid-jejunum were placed in $10 \%$ buffered formaldehyde at room temperature until further processing for histological evaluation.

\subsection{Laboratory Analyses}

For protein extraction mid-jejunum mucosa samples were thawed on ice and $1 \mathrm{~g}$ of the sample was placed in sterile tube ( $5 \mathrm{~mL}$ tube, Eppendorf, Hamburg, Germany) followed by addition of $2 \mathrm{~mL}$ of PBS (MP Biomedicals, Inc., Santa Ana, CA, USA). Samples were homogenized (Tissuemiser, Thermo Fisher Scientific, Waltham, MA, USA) for $30 \mathrm{~s}$ and centrifuged at $87,000 \times \mathrm{g}$ for $20 \mathrm{~min}$ on ice. The supernatant was subdivided into vials stored at $-80^{\circ} \mathrm{C}$ until being used to evaluate antioxidant status, immune response, and intestinal barrier function in mid-jejunum mucosa relative to the protein content of samples (PierceTM BCA Protein Assay Kit, Thermo Fisher Scientific, Waltham, MA, USA). Protein quantification started by mixing $25 \mu \mathrm{L}$ of each sample with $200 \mu \mathrm{L}$ of working reagent provided in the kit in a microplate well (96-Well EIA/RIA Plates, Corning, Corning, NY, USA), followed by $30 \mathrm{~s}$ incubation in plate shaker. The plate was covered with clear adhesive strip and incubated for $30 \mathrm{~min}$ at $37^{\circ} \mathrm{C}$. The plate was cooled to room temperature and wells were read at $562 \mathrm{~nm}$.

The quantification of protein carbonyls (STA-310, Cell Biolabs, Inc., San Diego, CA, USA) as an index of oxidized proteins is described by Shen et al. [89]. Briefly, the protein content of each sample determined in the previous assay was diluted to $10 \mu \mathrm{g} / \mathrm{mL}$. Diluted samples $(100 \mu \mathrm{L})$ were pipetted into wells and incubated for $2 \mathrm{~h}$ at $37^{\circ} \mathrm{C}$. Each well was washed three times with $250 \mu \mathrm{L}$ of PBS (MP Biomedicals, Inc., Santa Ana, CA, USA) and $100 \mu \mathrm{L}$ of working solution supplied in the kit added before plate incubation in the dark for $45 \mathrm{~min}$. Each well was washed with $250 \mu \mathrm{L}$ of PBS/ethanol $(1: 1, v / v)$ and incubated for $5 \mathrm{~min}$ in an orbital shaker; this procedure was repeated four times. Each well was washed with $250 \mu \mathrm{L}$ of PBS twice, $200 \mu \mathrm{L}$ of blocking solution was added, and the plate was incubated for $1 \mathrm{~h}$ in an orbital shaker. Each well was washed with $250 \mu \mathrm{L}$ of washing buffer three times and $100 \mu \mathrm{L}$ of anti-dinitrophenylhydrazine antibody supplied in the kit were added according to dilutions recommended by the manufacturer. The plate was incubated in an orbital shaker for $1 \mathrm{~h}$. Each well was washed with $250 \mu \mathrm{L}$ of washing buffer three times and $100 \mu \mathrm{L}$ of horseradish peroxidase antibody were added for incubation for $1 \mathrm{~h}$ in an orbital shaker. Each well was washed with $250 \mu \mathrm{L}$ of washing buffer five times, $100 \mu \mathrm{L}$ of substrate were added, and $100 \mu \mathrm{L}$ of stop solution were added after the onset color development. The wells were read at $450 \mathrm{~nm}$.

Malondialdehydes (STA-330, Cell Biolabs, Inc., San Diego, CA, USA) were measured by incubating for $5 \mathrm{~min} 100 \mu \mathrm{L}$ of each sample in equal volume of SDS lysis solution provided in the kit. Followed by incubation at $95^{\circ} \mathrm{C}$ for $45 \mathrm{~min}$ with $250 \mu \mathrm{L}$ of the reagent $(130 \mathrm{mg}$ of thiobarbituric acid in $25 \mathrm{~mL}$ of diluent) supplied in the kit, which had the $\mathrm{pH}$ adjusted (Accumet AB15 pH Meter, Fisher Scientific, Hampton, NH, USA) to 3.5 with sodium hydroxide. Tubes were cooled in for $5 \mathrm{~min}$ and centrifuged at $4000 \times g$ for $15 \mathrm{~min}$. The supernatant $(300 \mu \mathrm{L})$ was vigorously mixed with $300 \mu \mathrm{L}$ of butanol for $2 \mathrm{~min}$ and centrifuged at $10,000 \times g$ for $5 \mathrm{~min}$. The supernatant $(200 \mu \mathrm{L})$ was transferred to a microplate (96-Well EIA/RIA Plates, Corning, Corning, NY, USA) and samples were read at $532 \mathrm{~nm}$. 
Tumor necrosis factor- $\alpha$ (PTA00, R\&D Systems, Inc., Minneapolis, MN, USA) was measured by pipetting $50 \mu \mathrm{L}$ of assay diluent supplied in the kit with $50 \mu \mathrm{L}$ of samples into wells. The plate was covered with clear adhesive strip and incubated for $2 \mathrm{~h}$. Each well was washed five times with $300 \mu \mathrm{L}$ of washing buffer, $100 \mu \mathrm{L}$ of TNF- $\alpha$ conjugate supplied in the kit were added, and the plate was incubated following same specifications. Each well was washed five times with $300 \mu \mathrm{L}$ of washing buffer, $100 \mu \mathrm{L}$ of substrate solution supplied in the kit were added to each well, and the plate was incubated for $30 \mathrm{~min}$ in the dark. After incubation, $100 \mu \mathrm{L}$ of stop solution supplied in the kit were added and wells were read 450 and $570 \mathrm{~nm}$ to obtain reading at 570 subtracted from $450 \mathrm{~nm}$.

Iterleukin-8 quantification (P8000, R\&D Systems, Inc., Minneapolis, MN, USA) was performed by pipetting $50 \mu \mathrm{L}$ of assay diluent supplied in the kit with $100 \mu \mathrm{L}$ of samples into wells. The plate was covered with clear adhesive strip and incubated for $2 \mathrm{~h}$ in orbital shaker at $500 \mathrm{rpm}$. Each well was washed five times with $300 \mu \mathrm{L}$ of washing buffer, $200 \mu \mathrm{L}$ of porcine IL-8 conjugate supplied in the kit were added, and the plate was incubated following same specifications. Each well was washed five times with $300 \mu \mathrm{L}$ of washing buffer, $120 \mu \mathrm{L}$ of substrate solution supplied in the kit were added, and the plate incubated for $30 \mathrm{~min}$ in the dark. After incubation, $120 \mu \mathrm{L}$ of stop solution supplied in the kit were added and wells were read 450 and $570 \mathrm{~nm}$ to obtain reading at 570 subtracted from $450 \mathrm{~nm}$.

Immunoglobulin A (E100-102, Bethyl Laboratories, Inc., Montgomery, TX, USA) and IgG (E100-104, Bethyl Laboratories, Inc., Montgomery, TX, USA) were measured by pipetting $100 \mu \mathrm{L}$ of their respective affinity purified antibody in each well according to the kit dilution. The plate was incubated for 1 h. Each well was washed five times with $260 \mu \mathrm{L}$ of washing buffer supplied in the kit, $200 \mu \mathrm{L}$ of blocking buffer supplied in the kit were added, and the plate was incubated for $30 \mathrm{~min}$. Each well was washed five times with $260 \mu \mathrm{L}$ of washing buffer, $100 \mu \mathrm{L}$ of samples were added and incubated for $30 \mathrm{~min}$. Each well was washed five times with $260 \mu \mathrm{L}$ of washing buffer, $100 \mu \mathrm{L}$ of diluted horseradish peroxidase supplied in the kit were added, and the plate was incubated for $1 \mathrm{~h}$. Each well was washed five times with $260 \mu \mathrm{L}$ of washing buffer, $100 \mu \mathrm{L}$ of tetramethylbenzidine substrate were added, and the plate was incubated in the dark for $15 \mathrm{~min}$. Sulfuric acid $(100 \mu \mathrm{L})$ at $0.18 \mathrm{M}$ was used as stop solution. The plate was read at $450 \mathrm{~nm}$.

For measurement of total glutathione, a different protein extraction method was used, as recommended by the kit manufacturer total glutathione (STA-312, Cell Biolabs, Inc., San Diego, CA, USA). Mid-jejunum mucosa (100 mg) and $1 \mathrm{~mL}$ of metaphosphoric acid at $5 \%$ were mixed and homogenized with a glass pestle. The homogenate was centrifuged at $64,000 \times g$ for $15 \mathrm{~min}$. The supernatant was used for total glutathione determination total glutathione (STA-312, Cell Biolabs, Inc., San Diego, CA, USA). Glutathione reductase solution $(25 \mu \mathrm{L})$, NADPH solution $(25 \mu \mathrm{L})$ supplied in the kit, and samples $(100 \mu \mathrm{L})$ were added to each well. The chromogen solution $(100 \mu \mathrm{L})$ supplied in the kit was added to each well and the plate was read at $405 \mathrm{~nm}$ every $2 \mathrm{~min}$ during $10 \mathrm{~min}$. All wavelengths (for quantifications of protein, protein carbonyls, malondialdehydes, total glutathione, TNF- $\alpha$, IL-8, IgA, and IgG) were read at the same microplate reader (Synergy HT, Biotek, Winooski, VT, USA).

Ileal digesta was freeze dried (SP Scientific, Virtis 24DX48 GPFD/300820, Warminster, PA, USA) and ground. Subsamples of ground material were analyzed for apparent ileal digestibility of dry matter [90], gross energy (6200 Calorimeter, Parr Instrument Company, Moline, IL, USA), nitrogen (method 990.03, [91], ATC Scientific, North Little Rock, AR, USA), and ether extract (method 920.39, [91]).

Fixed mid-jejunal tissue was removed from $10 \%$ buffered formaldehyde after two weeks for the obtainment of two transversal cuts that were transferred histological cassettes and submerged in $70 \%$ ethanol. Mid-jejunal cuts were included in paraffin for assembling histological slides after staining for Ki-67 antigen. The immunohistochemistry staining with Ki-67 primary monoclonal antibody (1:500 dilution) followed by anti-mouse secondary antibody (1:2 dilution factor) and the use of diamino-benzamine reagent for color development was performed in accordance with methods previously described by Kim et. al. [20]. Ten pictures of each pig were used to measure gut morphology by a single researcher choosing a well-oriented villus and its associated crypt. Measurements included: 
villus width (at half of villus height), villus height (from tip of the villus to top of the crypt), crypt depth (from top to bottom of the crypt), and calculating villus height: crypt depth [86]. The proportion of proliferating cells in the crypt was also estimated by calculating the proportion of cells positive to Ki-67 after taking pictures at 40x in Sony Van-Ox S microscope (Opelco, Washington, DC, USA) and processing in ImageJS tool [92] for analysis as described by Holanda and Kim [86].

\subsection{Data Analyses and Interpretation}

The statistical analysis was performed using the mixed procedure of SAS 9.3 software (Cary, NC, USA). Factors, dietary mycotoxins and PYCW, and interaction were considered as main effects, whereas blocks, sex and initial body weight, were considered as random effects. Means were obtained by the LSMEANS statement. In case of interaction, treatments were compared with the PDIFF statement and tested by Tukey test. Results were considered statistically different for $p<0.05$ and were considered as tendency for $0.05 \leq p<0.10$.

Author Contributions: Conceptualization, S.W.K. and A.Y.; methodology, S.W.K. and A.Y.; formal analysis, D.M.H.; investigation, D.M.H.; resources, S.W.K. and A.Y.; data curation, D.M.H. and S.W.K.; writing-original draft preparation, D.M.H. and S.W.K.; writing—review and editing, D.M.H., S.W.K., and A.Y.; supervision, S.W.K.; project administration, S.W.K.; funding acquisition, S.W.K. All authors have read and agreed to the published version of the manuscript.

Funding: This research was funded by North Carolina Agricultural Foundation and Alltech Inc.

Acknowledgments: Financial supports from Alltech Inc. and North Carolina Agricultural Foundation.

Conflicts of Interest: The authors declare no conflict of interest.

\section{References}

1. Streit, E.; Naehrer, K.; Rodrigues, I.; Schatzmayr, G. Mycotoxin occurrence in feed and feed raw materials worldwide: Long-term analysis with special focus on Europe and Asia. J. Sci. Food Agric. 2013, 93, 2892-2899. [CrossRef] [PubMed]

2. Patriarca, A.; Pinto, V.F. Prevalence of mycotoxins in foods and decontamination. Curr. Opin. Food Sci. 2017, 14, 50-60. [CrossRef]

3. Gruber-Dorninger, C.; Jenkins, T.; Schatzmayr, G. Global mycotoxin occurrence in feed: A ten-year survey. Toxins 2019, 11, 375. [CrossRef] [PubMed]

4. Akande, K.E.; Abubakar, M.M.; Adegbola, T.A.; Bogoro, S.E. Nutritional and health implications of mycotoxins in animal feeds: A review. Pakistan J. Nutr. 2006, 5, 398-403.

5. Bertero, A.; Moretti, A.; Spicer, L.; Caloni, F. Fusarium molds and mycotoxins: Potential species-specific effects. Toxins 2018, 10, 244. [CrossRef]

6. Chaytor, A.C.; Hansen, J.A.; van Heugten, E.; See, M.T.; Kim, S.-W. Occurrence and decontamination of mycotoxins in swine feed. Asian Australas. J. Anim. Sci. 2011, 24, 723-738. [CrossRef]

7. Chaytor, A.C.; See, M.T.; Hansen, J.A.; De Souza, A.L.P.; Middleton, T.F.; Kim, S.W. Effects of chronic exposure of diets with reduced concentrations of aflatoxin and deoxynivalenol on growth and immune status of pigs. J. Anim. Sci. 2011, 89, 124-135. [CrossRef]

8. Weaver, A.C.; See, M.T.; Hansen, J.A.; Kim, Y.B.; de Souza, A.L.P.; Middleton, T.F.; Kim, S.W.; Middleton, T.F. The use of feed additives to reduce the effects of aflatoxin and deoxynivalenol on pig growth, organ health and immune status during chronic exposure. Toxins 2013, 5, 1261-1281. [CrossRef]

9. Khoshal, A.K.; Novak, B.; Martin, P.G.; Jenkins, T.; Neves, M.; Schatzmayr, G.; Oswald, I.P.; Pinton, P. Co-occurrence of DON and emerging mycotoxins in worldwide finished pig feed and their combined toxicity in intestinal cells. Toxins 2019, 11, 727. [CrossRef]

10. Lei, M.; Zhang, N.; Qi, D. In vitro investigation of individual and combined cytotoxic effects of aflatoxin B1 and other selected mycotoxins on the cell line porcine kidney 15. Exp. Toxicol. Pathol. 2013, 65, 1149-1157. [CrossRef]

11. Food and Drug Administration. Sec. 683.100 Action Levels for Aflatoxins in Animal Food Compliance Policy Guide Guidance for FDA Staff; U.S. Department of Health and Human Services: Rockville, MD, USA, 2019. 
12. European Commission. Commision Directive 2003/100/EC. 2003. Available online: https://eur-lex.europa.eu/ legal-content/EN/TXT/PDF/?uri=\%20CELEX:32003L0100\&from=EN (accessed on 3 June 2020).

13. Food and Drug Administration. Food and Drug Administration Compliance Program Guidance Manual; 2005. Available online: https://www.fda.gov/media/74766/download (accessed on 3 June 2020).

14. Publications Office of the European. Union Commission Recommendation (EU) 2016/1319 of 29 July 2016 Amending Recommendation 2006/576/EC as Regards Deoxynivalenol, Zearalenone and Ochratoxin A in Pet Food (Text with EEA Relevance), C/2016/4863; Publications Office of the European Union: Brussels, Belgium, 2016.

15. Ferrer, M.; Manyes, L.; Mañes, J.; Meca, G. Influence of prebiotics, probiotics and protein ingredients on mycotoxin bioaccessibility. Food Funct. 2015, 6, 987-994. [CrossRef] [PubMed]

16. Zhu, Y.; Hassan, Y.; Lepp, D.; Shao, S.; Zhou, T.; Zhu, Y.; Hassan, Y.I.; Lepp, D.; Shao, S.; Zhou, T. Strategies and methodologies for developing microbial detoxification systems to mitigate mycotoxins. Toxins (Basel) 2017, 9, 130. [CrossRef] [PubMed]

17. Dallies, N.; François, J.; Paquet, V. A new method for quantitative determination of polysaccharides in the yeast cell wall. Application to the cell wall defective mutants of Saccharomyces cerevisiae. Yeast 1998, 14, 1297-1306. [CrossRef]

18. Alexandre, H.; Guilloux-Benatier, M. Yeast autolysis in sparkling wine-A review. Aust. J. Grape Wine Res. 2006, 12, 119-127. [CrossRef]

19. Yiannikouris, A.; François, J.; Poughon, L.; Dussap, C.-G.; Bertin, G.; Jeminet, G.; Jouany, J.-P. Alkali extraction of $\beta$-d-glucans from Saccharomyces cerevisiae cell wall and study of their adsorptive properties toward zearalenone. J. Agric. Food Chem. 2004, 52, 3666-3673. [CrossRef]

20. Kim, S.W.; Holanda, D.M.; Gao, X.; Park, I.; Yiannikouris, A. Efficacy of a yeast cell wall extract to mitigate the effect of naturally co-occurring mycotoxins contaminating feed ingredients fed to young pigs: Impact on gut health, microbiome, and growth. Toxins 2019, 11, 633. [CrossRef] [PubMed]

21. Yiannikouris, A.; André, G.; Poughon, L.; François, J.; Dussap, C.-G.; Jeminet, G.; Bertin, G.; Jouany, J.-P. Chemical and conformational study of the interactions involved in mycotoxin complexation with $\beta$-d-glucans. Biomacromolecules 2006, 7, 1147-1155. [CrossRef]

22. Roto, S.M.; Rubinelli, P.M.; Ricke, S.C. An introduction to the avian gut microbiota and the effects of yeast-based prebiotic-type compounds as potential feed additives. Front. Vet. Sci. 2015, 2, 28. [CrossRef]

23. Shurson, G. Yeast and yeast derivatives in feed additives and ingredients: Sources, characteristics, animal responses, and quantification methods. Anim. Feed. Sci. Technol. 2018, 235, 60-76. [CrossRef]

24. Kong, C.; Shin, S.Y.; Kim, B.G. Evaluation of mycotoxin sequestering agents for aflatoxin and deoxynivalenol: An in vitro approach. SpringerPlus 2014, 3, 1-4. [CrossRef]

25. Kogan, G.; Kocher, A. Role of yeast cell wall polysaccharides in pig nutrition and health protection. Livest. Sci. 2007, 109, 161-165. [CrossRef]

26. Fouhse, J.; Zijlstra, R.; Willing, B.P. The role of gut microbiota in the health and disease of pigs. Anim. Front. 2016, 6, 30-36. [CrossRef]

27. Andretta, I.; Kipper, M.; Lehnen, C.R.; Hauschild, L.; Vale, M.M.; Lovatto, P.A. Meta-analytical study of productive and nutritional interactions of mycotoxins in growing pigs. Animal 2011, 6, 1476-1482. [CrossRef] [PubMed]

28. FDA Guidance for industry and FDA: Advisory Levels for Deoxynivalenol (DON) in Finished Wheat Products for Human Consumption and Grains and Grain By-Products Used for Animal Feed. Available online: https://www.fda.gov/regulatory-information/search-fda-guidance-documents/guidance-industryand-fda-advisory-levels-deoxynivalenol-don-finished-wheat-products-human (accessed on 22 May 2019).

29. Alizadeh, A.; Braber, S.; Akbari, P.; Kraneveld, A.D.; Garssen, J.; Fink-Gremmels, J. Deoxynivalenol and its modified forms: Are there major differences? Toxins 2016, 8, 334. [CrossRef] [PubMed]

30. Gratz, S.W.; Currie, V.; Richardson, A.J.; Duncan, G.; Holtrop, G.; Farquharson, F.; Louis, P.; Pinton, P.; Oswald, I.P.; Björkroth, J. Porcine small and large intestinal microbiota rapidly hydrolyze the masked mycotoxin deoxynivalenol-3-glucoside and release deoxynivalenol in spiked batch cultures in vitro. Appl. Environ. Microbiol. 2018, 84, 1-9. [CrossRef]

31. Broekaert, N.; Devreese, M.; Van Bergen, T.; Schauvliege, S.; De Boevre, M.; de Saeger, S.; Vanhaecke, L.; Berthiller, F.; Michlmayr, H.; Malachová, A.; et al. In vivo contribution of deoxynivalenol-3- $\beta$-d-glucoside to deoxynivalenol exposure in broiler chickens and pigs: Oral bioavailability, hydrolysis and toxicokinetics. Arch. Toxicol. 2016, 91, 699-712. [CrossRef] 
32. Eriksen, G.S.; Pettersson, H.; Lundh, T. Comparative cytotoxicity of deoxynivalenol, nivalenol, their acetylated derivatives and de-epoxy metabolites. Food Chem. Toxicol. 2004, 42, 619-624. [CrossRef]

33. Payros, D.; Alassane-Kpembi, I.; Pierron, A.; Loiseau, N.; Pinton, P.; Oswald, I.P. Toxicology of deoxynivalenol and its acetylated and modified forms. Arch. Toxicol. 2016, 90, 2931-2957. [CrossRef]

34. Cheat, S.; Gerez, J.; Cognié, J.; Alassane-Kpembi, I.; Bracarense, A.P.F.; Raymond-Letron, I.; Oswald, I.P.; Kolf-Clauw, M. Nivalenol has a greater impact than deoxynivalenol on pig jejunum mucosa in vitro on explants and in vivo on intestinal loops. Toxins 2015, 7, 1945-1961. [CrossRef]

35. Escrivá, L.; Font, G.; Manyes, L. In vivo toxicity studies of fusarium mycotoxins in the last decade: A review. Food Chem. Toxicol. 2015, 78, 185-206. [CrossRef]

36. Prelusky, D.B.; Trenholm, H.L. The efficacy of various classes of anti-emetics in preventing deoxynivalenol-induced vomiting in swine. Nat. Toxins 1993, 1, 296-302. [CrossRef] [PubMed]

37. Fioramonti, J.; Dupuy, C.; Dupuy, J.; Bueno, L. The mycotoxin, deoxynivalenol, delays gastric emptying through serotonin-3 receptors in rodents. J. Pharmacol. Exp. Ther. 1993, 266, 1255-1260. [PubMed]

38. Ripken, D.; van der Wielen, N.; Wortelboer, H.M.; Meijerink, J.; Witkamp, R.F.; Hendriks, H.F. Nutrient-induced glucagon like peptide-1 release is modulated by serotonin. J. Nutr. Biochem. 2016, 32, 142-150. [CrossRef] [PubMed]

39. Flannery, B.M.; Clark, E.S.; Pestka, J.J. Anorexia induction by the trichothecene deoxynivalenol (vomitoxin) is mediated by the release of the gut satiety hormone peptide YY. Toxicol. Sci. 2012, 130, 289-297. [CrossRef] [PubMed]

40. Pestka, J.J. Deoxynivalenol: Mechanisms of action, human exposure, and toxicological relevance. Arch. Toxicol. 2010, 84, 663-679. [CrossRef]

41. Bae, H.; Gray, J.S.; Li, M.; Vines, L.; Kim, J.; Pestka, J.J. Hematopoietic cell kinase associates with the 40S ribosomal subunit and mediates the ribotoxic stress response to deoxynivalenol in mononuclear phagocytes. Toxicol. Sci. 2010, 115, 444-452. [CrossRef]

42. Marin, D.E.; Taranu, I.; Bunaciu, R.P.; Pascale, F.; Tudor, D.S.; Avram, N.; Sarca, M.; Cureu, I.; Criste, R.D.; Suta, V.; et al. Changes in performance, blood parameters, humoral and cellular immune responses in weanling piglets exposed to low doses of aflatoxin. J. Anim. Sci. 2002, 80, 1250-1257. [CrossRef]

43. Wu, W.; Bates, M.A.; Bursian, S.J.; Flannery, B.; Zhou, H.-R.; Link, J.E.; Zhang, H.; Pestka, J.J. Peptide YY3-36 and 5-hydroxytryptamine mediate emesis induction by trichothecene deoxynivalenol (vomitoxin). Toxicol. Sci. 2013, 133, 186-195. [CrossRef]

44. Jo, H.; Kong, C.; Song, M.; Kim, B.J. Effects of dietary deoxynivalenol and zearalenone on apparent ileal digestibility of amino acids in growing pigs. Anim. Feed. Sci. Technol. 2016, 219, 77-82. [CrossRef]

45. Montagne, L.; Boudry, G.; Favier, C.; Le Huërou-Luron, I.; Lallès, J.-P.; Sève, B. Main intestinal markers associated with the changes in gut architecture and function in piglets after weaning. Br. J. Nutr. 2007, 97, 45-57. [CrossRef]

46. Gilbert, H.; Bidanel, J.-P.; Gruand, J.; Caritez, J.-C.; Billon, Y.; Guillouet, P.; Lagant, H.; Noblet, J.; Sellier, P. Genetic parameters for residual feed intake in growing pigs, with emphasis on genetic relationships with carcass and meat quality traits. J. Anim. Sci. 2007, 85, 3182-3188. [CrossRef] [PubMed]

47. Patience, J.F.; Serao, M.R.; Gutiérrez, N.A. A review of feed efficiency in swine: Biology and application. J. Anim. Sci. Biotechnol. 2015, 6, 33. [CrossRef] [PubMed]

48. Weaver, A.C.; See, M.T.; Kim, S.W. Protective effect of two yeast based feed additives on pigs chronically exposed to deoxynivalenol and zearalenone. Toxins 2014, 6, 3336-3353. [CrossRef] [PubMed]

49. Gerez, J.R.; Pinton, P.; Callu, P.; Grosjean, F.; Oswald, I.P.; Bracarense, A.P.F. Deoxynivalenol alone or in combination with nivalenol and zearalenone induce systemic histological changes in pigs. Exp. Toxicol. Pathol. 2015, 67, 89-98. [CrossRef] [PubMed]

50. Schell, T.C.; Lindemann, M.D.; Kornegay, E.T.; Blodgett, D.J. Effects of feeding aflatoxin-contaminated diets with and without clay to weanling and growing pigs on performance, liver function, and mineral metabolism. Jounal Anim. Sci. 1993, 71, 1209-1218. [CrossRef] [PubMed]

51. Dänicke, S.; Beineke, A.; Berk, A.; Kersten, S.; Dänicke, S.; Beineke, A.; Berk, A.; Kersten, S. Deoxynivalenol $(\mathrm{DON})$ contamination of feed and grinding fineness: Are there interactive implications on stomach integrity and health of piglets? Toxins (Basel) 2017, 9, 16. [CrossRef]

52. Yu, F.L. Mechanism of aflatoxin B1 inhibition of rat hepatic nuclear RNA synthesis. J. Boil. Chem. 1977, $252,3245-3251$. 
53. Zimmermann, C.; da Cruz, I.B.M.; Cadoná, F.; Machado, A.; Assmann, C.E.; Schlemmer, K.; Zanette, R.A.; Leal, D.B.R.; Santurio, J.M. Cytoprotective and genoprotective effects of $\beta$-glucans against aflatoxin B1-induced DNA damage in broiler chicken lymphocytes. Toxicol. In Vitro 2015, 29, 538-543. [CrossRef]

54. Wróblewski, F. The clinical significance of alterations in transaminase activities of serum and other body fluids. Adv. Clin. Chem. 1958, 1, 313-351. [CrossRef]

55. Cicognani, C.; Malavolti, M.; Morselli-Labate, A.M.; Zamboni, L.; Sama, C.; Barbara, L. Serum lipid and lipoprotein patterns in patients with liver cirrhosis and chronic active hepatitis. Arch. Intern. Med. 1997, 157, 792. [CrossRef]

56. Horton, J.D.; Goldstein, J.L.; Brown, M.S. SREBPs: Activators of the complete program of cholesterol and fatty acid synthesis in the liver. J. Clin. Investig. 2002, 109, 1125-1131. [CrossRef] [PubMed]

57. Ytrebø, L.M.; Sen, S.; Rose, C.; Davies, N.A.; Nedredal, G.I.; Fuskevaag, O.-M.; Have, G.A.M.T.; Prinzen, F.W.; Williams, R.; Deutz, N.; et al. Systemic and regional haemodynamics in pigs with acute liver failure and the effect of albumin dialysis. Scand. J. Gastroenterol. 2006, 41, 1350-1360. [CrossRef] [PubMed]

58. Sumathi, T.; Devaraj, S.N. Effect of Bacopa monniera on liver and kidney toxicity in chronic use of opioids. Phytomedicine 2009, 16, 897-903. [CrossRef]

59. Lu, N.; Jang, Y.D.; Wang, D.; Monegue, H.J.; Adedokun, S.; Rentfrow, G.; Lindemann, M. 193 Allometric examination of visceral organ size, carcass characteristics, and blood clinical chemistry of pigs fed 20\% DDGS diets from 30 to $150 \mathrm{Kg}$. J. Anim. Sci. 2018, 96, 102-103. [CrossRef]

60. Baum, N.; Dichoso, C.C.; Carlton, C. Blood urea nitrogen and serum creatinine. Urology 1975, 5, 583-588. [CrossRef]

61. Vilstrup, H. Synthesis of urea after stimulation with amino acids: Relation to liver function. Gut 1980, 21, 990-995. [CrossRef] [PubMed]

62. Battersby, C.; Hickman, R.; Saunders, S.J.; Terblanche, J. Liver function in the pig: 1. The effects of 30 minutes' normothermic ischaemia. Br. J. Surg. 1974, 61, 27-32. [CrossRef]

63. Green, R.M.; Flamm, S. AGA technical review on the evaluation of liver chemistry tests. Gastroenterology 2002, 123, 1367-1384. [CrossRef]

64. Hollinger, K.; Yang, C.X.; Montz, R.E.; Nonneman, D.; Ross, J.W.; Selsby, J.T. Dystrophin insufficiency causes selective muscle histopathology and loss of dystrophin-glycoprotein complex assembly in pig skeletal muscle. FASEB J. 2013, 28, 1600-1609. [CrossRef]

65. Nyblom, H.; Berggren, U.; Balldin, J.; Olsson, R. High ast/alt ratio may indicate advanced alcoholic liver disease rather than heavy drinking. Alcohol Alcohol. 2004, 39, 336-339. [CrossRef]

66. Wang, L.; Hou, Y.; Yi, D.; Li, Y.; Ding, B.; Zhu, H.; Liu, J.; Xiao, H.; Wu, G. Dietary supplementation with glutamate precursor $\alpha$-ketoglutarate attenuates lipopolysaccharide-induced liver injury in young pigs. Amino Acids 2015, 47, 1309-1318. [CrossRef] [PubMed]

67. Chen, F.; Ma, Y.; Xue, C.; Ma, J.; Xie, Q.; Wang, G.; Bi, Y.; Cao, Y. The combination of deoxynivalenol and zearalenone at permitted feed concentrations causes serious physiological effects in young pigs. J. Vet. Sci. 2008, 9, 39-44. [CrossRef] [PubMed]

68. Le Blay, G.; Blottière, H.M.; Ferrier, L.; Le Foll, E.; Bonnet, C.; Galmiche, J.P.; Cherbut, C. Short-chain fatty acids induce cytoskeletal and extracellular protein modifications associated with modulation of proliferation on primary culture of rat intestinal smooth muscle cells. Dig. Dis. Sci. 2000, 45, 1623-1630. [CrossRef] [PubMed]

69. Liu, G.; Yu, L.; Martínez, Y.; Ren, W.; Ni, H.J.; Al-Dhabi, N.A.; Duraipandiyan, V.; Yin, Y. Dietary Saccharomyces cerevisiae cell wall extract supplementation alleviates oxidative stress and modulates serum amino acids profiles in weaned piglets. Oxidative Med. Cell. Longev. 2017, 2017, 1-7. [CrossRef] [PubMed]

70. Reddy, K.E.; Song, J.; Lee, H.-J.; Kim, M.; Kim, D.-W.; Jung, H.J.; Kim, B.; Lee, Y.K.; Yu, D.; Oh, Y.K.; et al. Effects of high levels of deoxynivalenol and zearalenone on growth performance, and hematological and immunological parameters in pigs. Toxins 2018, 10, 114. [CrossRef]

71. Ponchon, G.; Kennan, A.L.; DeLuca, H.F. “Activation” of vitamin D by the liver. J. Clin. Investig. 1969, 48, 2032-2037. [CrossRef]

72. Lawson, D.E.M.; Fraser, D.R.; Kodicek, E.; Morris, H.R.; Williams, D.H. Identification of 1,25-dihydroxycholecalciferol, a new kidney hormone controlling calcium metabolism. Nature 1971, 230, 228-230. [CrossRef] 
73. Glahn, R.P.; Beers, K.W.; Bottje, W.G.; Wideman, R.F.; Huff, W.E.; Thomas, W. Aflatoxicosis alters avian renal function, calcium, and vitamin d metabolism. J. Toxicol. Environ. Health Part A 1991, 34, 309-321. [CrossRef]

74. Kataria, A.K.; Kataria, N. Evaluation of oxidative stress in pigs affected with classical swine fever. Int. J. Bioflux Soc. 2012, 2, 35-38.

75. Lauridsen, C.; Jensen, S.K. Influence of supplementation of all-rac- $\alpha$-tocopheryl acetate preweaning and vitamin C postweaning on $\alpha$-tocopherol and immune responses of piglets1. J. Anim. Sci. 2005, 83, 1274-1286. [CrossRef]

76. Lessard, M.; Savard, C.; Deschene, K.; Lauzon, K.; Pinilla, V.; Gagnon, C.A.; Lapointe, J.; Guay, F.; Chorfi, Y. Impact of deoxynivalenol (DON) contaminated feed on intestinal integrity and immune response in swine. Food Chem. Toxicol. 2015, 80,7-16. [CrossRef] [PubMed]

77. Pasternak, J.A.; Aiyer, V.I.A.; Hamonic, G.; Beaulieu, A.D.; Columbus, D.; Wilson, H.L. Molecular and physiological effects on the small intestine of weaner pigs following feeding with deoxynivalenol-contaminated feed. Toxins 2018, 10, 40. [CrossRef] [PubMed]

78. Nochta, I.; Halas, V.; Tossenberger, J.; Babinszky, L. Effect of different levels of mannan-oligosaccharide supplementation on the apparent ileal digestibility of nutrients, N-balance and growth performance of weaned piglets. J. Anim. Physiol. Anim. Nutr. 2010, 94, 747-756. [CrossRef] [PubMed]

79. Miguel, J.C.; Rodriguez-Zas, S.L.; Pettigrew, J.E. Efficacy of a mannan oligosaccharide (Bio-Mosß) for improving nursery pig performance. J. Swine Health Prod. 2004, 12, 296-307.

80. Hahn, T.-W.; Lohakare, J.D.; Lee, S.L.; Moon, W.K.; Chae, B.J. Effects of supplementation of $\beta$-glucans on growth performance, nutrient digestibility, and immunity in weanling pigs. J. Anim. Sci. 2006, 84, 1422-1428. [CrossRef] [PubMed]

81. Lam, K.-L.; Cheung, P.C.-K. Non-digestible long chain beta-glucans as novel prebiotics. Bioact. Carbohydr. Diet. Fibre 2013, 2, 45-64. [CrossRef]

82. Chen, L.; Zhu, M.; Chen, M.-X.; Fan, H.-B.; Fu, H.-L.; Zhou, J.-Y.; Zhai, Z.-Y.; Gao, C.-Q.; Yan, H.-C.; Wang, X.-Q. Acute exposure to deoxynivalenol inhibits porcine enteroid activity via suppression of the Wnt/ $\beta$-catenin pathway. Toxicol. Lett. 2019, 305, 19-31. [CrossRef]

83. Dänicke, S.; Goyarts, T.; Doll, S.; Grove, N.; Spolders, M.; Flachowsky, G. Effects of the Fusarium toxin deoxynivalenol on tissue protein synthesis in pigs. Toxicol. Lett. 2006, 165, 297-311. [CrossRef]

84. National Research Council (NRC). Nutrition Requirements of Swine, 11th ed.; National Academy Press: Washington, DC, USA, 2012.

85. Jackson, L.C.; Kudupoje, M.B.; Yiannikouris, A. Simultaneous multiple mycotoxin quantification in feed samples using three isotopically labeled internal standards applied for isotopic dilution and data normalization through ultra-performance liquid chromatography/electrospray ionization tandem mass spe. Rapid Commun. Mass Spectrom. 2012, 26, 2697-2713. [CrossRef]

86. Holanda, D.M.; Kim, S.W. Efficacy of mycotoxin detoxifiers on health and growth of newly-weaned pigs under chronic dietary challenge of deoxynivalenol. Toxins 2020, 12, 311. [CrossRef]

87. Duarte, M.E.; Zhou, F.X.; Dutra, W.M.; Kim, S.W. Dietary supplementation of xylanase and protease on growth performance, digesta viscosity, nutrient digestibility, immune and oxidative stress status, and gut health of newly weaned pigs. Anim. Nutr. 2019, 5, 351-358. [CrossRef] [PubMed]

88. Adeola, O.; King, D.E. Developmental changes in morphometry of the small intestine and jejunal sucrase activity during the first nine weeks of postnatal growth in pigs. J. Anim. Sci. 2006, 84, 112-118. [CrossRef] [PubMed]

89. Shen, Y.B.; Weaver, A.C.; Kim, S.W. Effect of feed grade L-methionine on growth performance and gut health in nursery pigs compared with conventional DL-methionine. J. Anim. Sci. 2014, 92, 5530-5539. [CrossRef] [PubMed]

90. Passos, A.A.; Park, I.; Ferket, P.; von Heimendahl, E.; Kim, S.W. Effect of dietary supplementation of xylanase on apparent ileal digestibility of nutrients, viscosity of digesta, and intestinal morphology of growing pigs fed corn and soybean meal based diet. Anim. Nutr. 2015, 1, 19-23. [CrossRef] 
91. AOAC international. AOAC International Guidelines for Laboratories Performing Microbiological and Chemical Analyses of Food and Pharmaceuticals: An Aid to Interpretation of ISO/IEC 17025: 2005; AOAC International AOAC: Rockville, MD, USA, 2006.

92. Almeida, J.S.; Iriabho, E.E.; Gorrepati, V.L.; Wilkinson, S.R.; Grüneberg, A.; Robbins, D.E.; Hackney, J.R. ImageJS: Personalized, participated, pervasive, and reproducible image bioinformatics in the web browser. J. Pathol. Inform. 2012, 3, 25. [CrossRef] 